Article

\title{
Short-Term Meteorological and Environmental Signals Recorded in a Firn Core from a High-Accumulation Site on Plateau Laclavere, Antarctic Peninsula
}

\author{
Kirstin Hoffmann-Abdi ${ }^{1,2, *(\mathbb{D})}$, Francisco Fernandoy ${ }^{3}\left(\mathbb{D}\right.$, Hanno Meyer $^{1}$, Johannes Freitag ${ }^{4}$ (D), Thomas Opel $^{1}(\mathbb{D}$, \\ Joseph R. McConnell ${ }^{5}$ and Christoph Schneider ${ }^{2}$
}

1 Alfred Wegener Institute, Helmholtz Centre for Polar and Marine Research, Research Unit Potsdam, Telegrafenberg A45, 14473 Potsdam, Germany; Hanno.Meyer@awi.de (H.M.); Thomas.Opel@awi.de (T.O.)

2 Geographisches Institut, Humboldt-Universität zu Berlin, Unter den Linden 6, 10099 Berlin, Germany; christoph.schneider@geo.hu-berlin.de

3 Facultad de Ingeniería, Universidad Andrés Bello, Viña del Mar 2531015, Chile; francisco.fernandoy@unab.cl

4 Alfred Wegener Institute, Helmholtz Centre for Polar and Marine Research, Am Alten Hafen 26, 27568 Bremerhaven, Germany; Johannes.Freitag@awi.de

5 Division of Hydrologic Sciences, Desert Research Institute, 2215 Raggio Parkway, Reno, NV 89512, USA; Joe.McConnell@dri.edu

* Correspondence: Kirstin.Hoffmann@awi.de

Citation: Hoffmann-Abdi, K.; Fernandoy, F.; Meyer, H.; Freitag, J.; Opel, T.; McConnell, J.R.; Schneider, C. Short-Term Meteorological and Environmental Signals Recorded in a Firn Core from a High-Accumulation Site on Plateau Laclavere, Antarctic Peninsula. Geosciences 2021, 11, 428. https://doi.org/10.3390/geosciences 11100428

Academic Editors: Christina Biasi and Jesus Martinez-Frias

Received: 4 September 2021

Accepted: 8 October 2021

Published: 15 October 2021

Publisher's Note: MDPI stays neutral with regard to jurisdictional claims in published maps and institutional affiliations.

Copyright: (c) 2021 by the authors. Licensee MDPI, Basel, Switzerland. This article is an open access article distributed under the terms and conditions of the Creative Commons Attribution (CC BY) license (https:// creativecommons.org/licenses/by/ $4.0 /)$.

\begin{abstract}
High-accumulation sites are crucial for understanding the patterns and mechanisms of climate and environmental change in Antarctica since they allow gaining high-resolution proxy records from firn and ice. Here, we present new glacio- and isotope-geochemical data at sub-annual resolution from a firn core retrieved from an ice cap on Plateau Laclavere (LCL), northern Antarctic Peninsula, covering the period 2012-2015. The signals of two volcanic eruptions and two forest fire events in South America could be identified in the non-sea-salt sulphur and black carbon records, respectively. Mean annual snow accumulation on LCL amounts to $2500 \mathrm{~kg} \mathrm{~m}^{-2} \mathrm{a}^{-1}$ and exhibits low inter-annual variability. Time series of $\delta^{18} \mathrm{O}, \delta \mathrm{D}$ and $\mathrm{d}$ excess show no seasonal cyclicity, which may result from (1) a reduced annual temperature amplitude due to the maritime climate and (2) postdepositional processes. The firn core stratigraphy indicates strong surface melt on LCL during austral summers 2013 and 2015, likely related to large-scale warm-air advection from lower latitudes and temporal variations in sea ice extent in the Bellingshausen-Amundsen Sea. The LCL ice cap is a highly valuable natural archive since it captures regional meteorological and environmental signals as well as their connection to the South American continent.
\end{abstract}

Keywords: Antarctic Peninsula; firn cores; stable water isotopes; glacio-chemistry; high accumulation; surface melt

\section{Introduction}

The Antarctic Peninsula (AP) has long been considered as one of the "hot spots" of global climate warming since near-surface air temperatures on the AP have increased by more than $3^{\circ} \mathrm{C}$ since the 1950s [1-3]. The rapid atmospheric warming of the AP during the 20th century has been accompanied by a significant increase in precipitation and snow accumulation [4-6]. In addition, oceanic warming has caused the destabilisation and disintegration of ice shelves in the AP region and consequently, the acceleration of glacier discharge towards the ocean contributing to global sea level rise [7-11]. The most recent 100-year warming trend on the AP is unusual, but not unprecedented in the context of natural climate variability over the past two millennia $[12,13]$. The observed atmospheric and oceanic changes in the AP region have mainly been attributed to phase-changes of the Southern Annular Mode (SAM), which is the dominant mode of atmospheric variability in Southern Hemisphere high latitudes [14-17]. Since the mid-1970s, the SAM has shifted 
towards its positive phase, especially in austral summer and autumn $[15,18]$. This has been associated with a strengthening of the circumpolar vortex and, hence, an intensification (15-20\%) and poleward migration of the westerlies over the Southern Ocean $[14,15,19,20]$. For the northern AP region, this implies a reduced cold-air advection from the south, but an enhanced transport of warm and moist air from the Southern Ocean towards its western coast $[3,18,20]$.

Furthermore, sea ice extent in the Bellingshausen-Amundsen Sea at the western side of the AP has decreased throughout all seasons during recent decades, contrasting the generally positive Antarctic sea ice trends [21]. Sea ice variations in the BellingshausenAmundsen Sea are primarily driven by changes in the position and strength of the Amundsen Sea Low (ASL), which governs the direction and strength of the meridional flow over this sector [22]. Sea ice in the Weddell Sea on the eastern side of the AP shows seasonally different trends and its temporal variability is related to changes in the strength of the Weddell Gyre [21,23]. Both the depth of the ASL and the strength of the Weddell Gyre, and hence sea ice variability in the AP region, are influenced by phase-changes of large-scale climate modes, i.e., SAM and the El Niño Southern Oscillation [22-25].

Recent studies have drawn a new picture of climate change in the AP region, suggesting little or no air temperature change since the late 1990s [26,27]. The reversed air temperature trend has been linked to the increased advection of cold air by easterly to southeasterly winds because of greater cyclonic activity in the northern Weddell Sea [26,28].

In order to understand the recent climate variability of the AP region, long-term highresolution data such as air temperature, precipitation and accumulation rates are essential. However, their continuous observation only started in the second half of the 20th century, making the assessment of regional changes on different timescales difficult [2,29]. Proxy Proxy data, such as glacio-chemical data from firn and ice cores, may partly compensate for the lack of direct observations. The northern AP is a suitable region for such studies due to its very high snow accumulation rates of up to $>3000 \mathrm{~kg} \mathrm{~m}^{-2} \mathrm{a}^{-1}$, which allow the preservation of climate and environmental signals on sub-annual timescales [30,31]. Previous studies of Fernandoy et al. [31,32] have demonstrated that firn cores from the ice cap on Plateau Laclavere (LCL) can provide reliable climate proxy data. LCL was explored for the first time in austral summer 2010. Since then, more than ten firn cores of up to $20 \mathrm{~m}$ depth have been obtained from different altitudes and locations (Figure 1). In addition, more than 300 precipitation samples have been collected at Bernardo O'Higgins station $(\mathrm{OH})$ since 2008 in order to study the relation between near-surface air temperatures at $\mathrm{OH}$ and LCL, stable water isotope signals in LCL firn cores and precipitation reaching the northern AP. Fernandoy et al. [31] found a seasonally varying relationship between $\delta^{18} \mathrm{O}$ of precipitation and near-surface air temperatures at $\mathrm{OH}$ station for the period 2008-2014 and linked this observation to the formation of an inversion layer in the lower troposphere on the western side of the northern AP during months with sea ice coverage. Variations in the duration and extent of the sea ice cover also leads to seasonally varying lapse rates, which should be considered when comparing stable water isotope records from LCL with near-surface air temperatures [31]. A seasonal cyclicity was most clearly pronounced in the firn core $d$ excess records during 2008-2009, but no seasonality was found in $\delta^{18} \mathrm{O}$ or $\delta \mathrm{D}$, which both show no correlation with air temperatures at the nearby Bellingshausen $(\mathrm{BH})$ and $\mathrm{OH}$ stations. Based on the calculation of backward trajectories Fernandoy et al. [31,32] identified the Bellingshausen Sea (south of $60^{\circ} \mathrm{S}$ ) and the South Pacific Ocean $\left(50^{\circ}-60^{\circ} \mathrm{S}\right)$ as the main moisture sources for precipitating air masses reaching LCL. 
(a)


(b)

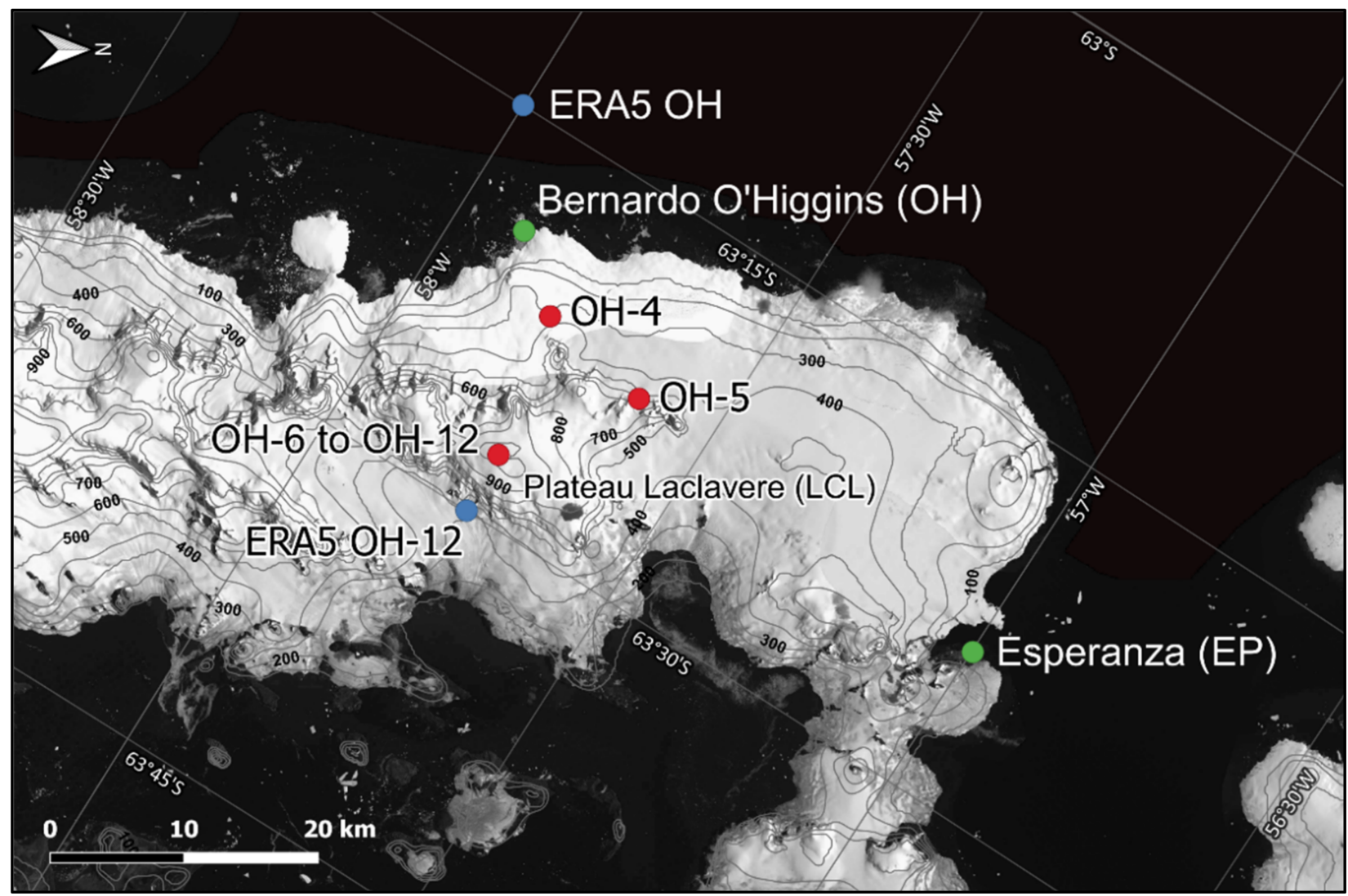

Figure 1. (a) Overview of the study area and (b) location of the drill sites of all firn cores (OH-4 to OH-12; red dots) retrieved from Plateau Laclavere (LCL) on the northern Antarctic Peninsula between 2008 and 2016. The green dots indicate the location of the Antarctic stations Bernardo O'Higgins (OH), Bellingshausen (BH), Esperanza (EP) and Comandante Ferraz (CF). The blue dots mark the location of the ERA5 grid points closest to $\mathrm{BH}$ and $\mathrm{OH}$ stations as well as to the $\mathrm{OH}-12$ drill site on LCL. Coordinates and altitudes of $\mathrm{OH}, \mathrm{BH}, \mathrm{EP}$ and $\mathrm{CF}$ stations and the $\mathrm{OH}-12$ drill location on LCL are given in Supplementary Table S1.

Here, we present high-resolution stratigraphic, glacio-chemical and stable water isotope data from a firn core drilled on Plateau Laclavere at the northern tip of the AP. In addition, precipitation samples collected at Bernardo O'Higgins station in 2015-2017 
are analysed for their stable water isotope composition extending the previously existing precipitation dataset for the site derived by Fernandoy et al. [30,31]. Since LCL is a highaccumulation site, our aim is to analyse whether short-term changes in meteorological conditions (e.g., warm-air events) are recorded by the firn core. We also investigate its potential to preserve southern hemispheric environmental signals (e.g., volcanic eruptions, forest fires) with a focus on the connection to the South American continent. The strong influence of the adjacent oceans (mainly the Bellingshausen Sea; to a lesser extent, the Weddell Sea) on the climate of the northern AP and the likely impact of post-depositional processes (wind drift, surface melt) on the proxy signals preserved in the firn core are assessed. The study provides an important basis for further paleoclimatic studies in the high-accumulation region of the northern AP based on the analysis of glacio-chemical firn core records.

\section{Materials and Methods}

\subsection{Fieldwork and Laboratory Analysis}

The firn core OH-12 was retrieved within the frame of a Chilean-German field campaign conducted on LCL in January 2016. LCL is located on the northernmost end of the $\mathrm{AP}$ at an altitude of about $1100 \mathrm{~m}$ above sea level (a.s.l.) and about $19 \mathrm{~km}$ south-east of $\mathrm{OH}$ station (12 $\mathrm{m}$ a.s.1.; Figure 1). It is about $3 \mathrm{~km}$ wide and $6 \mathrm{~km}$ long and has a flat surface. It is located at the divide between the warmer and moister western side and the colder and drier eastern side of the AP [32]. The ice cap reaches a maximum ice thickness of about $350 \mathrm{~m}$ [33]. The mean annual air temperature at the site is about $-7.5^{\circ} \mathrm{C}(2009-2014)$ [31].

The firn core OH-12 was drilled at about $1090 \mathrm{~m}$ altitude down to $19.93 \mathrm{~m}$ depth using a portable solar-powered and electrically operated ice-core drill (Backpack Drill; icedrill.ch AG; Figure 1). It was first stored at the Chilean Antarctic Station "Profesor Julio Escudero" on King George Island, South Shetland Islands, and then shipped to the Alfred Wegener Institute, Helmholtz Centre for Polar and Marine Research (AWI) in Bremerhaven, Germany. At the ice-core processing facilities of AWI Bremerhaven, the core was visually inspected for ice layers and lenses and their thicknesses were documented. Furthermore, high-resolution $(<1 \mathrm{~mm}$ ) density measurements were performed using X-ray microfocus computer tomography (ICE-CT; [34]). The core was then sampled at $0.05 \mathrm{~m}$ resolution $(n=414)$ and analysed for stable water isotopes at the ISOLAB Stable Isotope Facility of AWI Potsdam, Germany. Stable water isotopes were measured with cavity ring-down spectrometers L2130- $i$ and L2140-i (Picarro Inc.) coupled to an auto-sampler (L2130- $i$ : PAL HTC-xt, CTC Analytics AG; L2140-i: Picarro Autosampler, Picarro Inc.) using six repeated injections, from which the first three were discarded. The stable water isotope raw data were corrected for linear drift and memory effects following the procedures suggested by van Geldern and Barth [35]. Linear regression analysis was applied to calibrate the driftand memory-corrected stable water isotope data using four different in-house standards that have been calibrated to the international VSMOW2 (Vienna Standard Mean Ocean Water)/SLAP2 (Standard Light Antarctic Precipitation) scale. Stable water isotope ratios are reported in per mil (\%o) versus VSMOW2. Precision of the measurements is $\pm 0.08 \%$ o for $\delta^{18} \mathrm{O}$ and $\pm 0.5 \%$ o for $\delta \mathrm{D}$ (number of measured standards: 540 ).

In addition, analysis of stable water isotopes applying the described procedure was performed for precipitation samples collected at OH station between December 2015 and December $2017(n=133)$. Precipitation sampling took place according to the method described by Fernandoy et al. [31]. However, a significant number of the collected samples $(n=50)$ apparently have been isotopically modified, most likely during storage and transport, as they exhibited exceptional and unrealistic d excess values $(\leq-10 \%$ own to $-149 \%$ ). Hence, these samples were excluded from further data analysis and interpretation [31]. The considered data $(n=83)$ were then used to further constrain the Local Meteoric Water Line (LMWL) which has previously been derived by Fernandoy et al. [31,32] for the study site using stable water isotope data of recent precipitation collected at $\mathrm{OH}$ 
station from January 2008 to March $2009(n=139)$ and from March to November 2014 $(n=72)$.

Furthermore, $\mathrm{OH}-12$ was analysed in very high resolution (better than $10 \mathrm{~mm}$ ) for hydrogen peroxide $\left(\mathrm{H}_{2} \mathrm{O}_{2}\right)$, black carbon $(\mathrm{BC})$ and various chemical elements at the Trace Chemistry Laboratory of the Desert Research Institute (DRI) in Reno, Nevada, USA. Measurements were conducted according to methods described by Röthlisberger et al. [36] and McConnell et al. [37]. For the analyses, longitudinal subsections of the core (32 $\mathrm{mm} \times 32 \mathrm{~mm}$ in size) were melted continuously on a chemically inert, ultra-clean melt head (Continuous Flow Analysis [CFA]; [37]). Chemical elements were measured using two Thermo Finnigan Element2 High Resolution-Inductively Coupled Plasma-Mass Spectrometry (HR-ICP-MS) instruments. BC was analysed with a Single Particle Soot Photometer inter-cavity laser system (SP2, Droplet Measurement Technologies). In addition, values of sea-salt sodium (ssNa) and non-sea-salt sulphur (nssS) and the nssS/ssNa ratio were calculated from $\mathrm{Na}$ and $\mathrm{S}$ concentrations following the approaches of Röthlisberger et al. [38] and Sigl et al. [39], respectively, and using relative abundances from Bowen [40] (Equations (S1) and (S2) in the Supplementary Materials). While BC is used as a proxy for biomass burning and industrial pollution [41,42], the combined analysis of the nssS and nssS/ssNa records can provide information about the occurrence of volcanic eruptions $[43,44]$.

Corrected and calibrated $\delta^{18} \mathrm{O}$ and $\delta \mathrm{D}$ values were used to calculate the $\mathrm{d}$ excess $\left(\mathrm{d}\right.$ excess $\left.=\delta \mathrm{D}-8 \times \delta^{18} \mathrm{O} ;[45]\right)$ and to derive the $\delta^{18} \mathrm{O}-\delta \mathrm{D}$ relationship $\left(\delta \mathrm{D}=\mathrm{m} \times \delta^{18} \mathrm{O}+\mathrm{n}\right)$ for $\mathrm{OH}-12$. The $\mathrm{d}$ excess is a proxy for the conditions in the moisture source region, where lower sea surface temperatures and higher relative humidity would induce lower $\mathrm{d}$ excess values and vice versa [46-48]. The $\delta^{18} \mathrm{O}-\delta \mathrm{D}$ relationship of $\mathrm{OH}-12$ was compared to the Global Meteoric Water Line (GMWL) defined by Craig [49], and the site-specific LMWL derived from event-based precipitation samples as described above. Finally, highresolution profiles of density, $\delta^{18} \mathrm{O}, \delta \mathrm{D}$ and $\mathrm{d}$ excess as well as of all glacio-chemical parameters were generated.

\subsection{Age Model Construction and Time Series Analysis}

$\mathrm{OH}-12$ has been dated using annual layer counting (ALC) of high-resolution $\mathrm{H}_{2} \mathrm{O}_{2}$ measurements. $\mathrm{H}_{2} \mathrm{O}_{2}$ is photochemically produced in the atmosphere under the influence of solar UV radiation and water vapor, and therefore it reflects the annual insolation and air temperature cycles [50,51]. It is washed out of the atmosphere by precipitation and hence reaches the Earth's surface by wet deposition. Thus, $\mathrm{H}_{2} \mathrm{O}_{2}$ typically exhibits clear seasonal cycles following cyclic changes in solar radiation, making it a suitable parameter for dating [52-54].

Using the derived age model, time series of ice layer thickness and stable water isotopes of $\mathrm{OH}-12$ were constructed. Based on the high-resolution density record, accumulation rates were calculated for the study site. The records of $\mathrm{OH}-12$ stratigraphy and stable water isotope composition were then inter-compared as well as related to time series of meteorological parameters and sea ice extent (SIE) in the adjacent Bellingshausen-Amundsen and Weddell Seas.

Unfortunately, there are no available in situ measurements of meteorological parameters from LCL. The automatic weather stations (AWS) nearest to LCL are located at OH and $\mathrm{BH}$ stations and provide meteorological records at daily resolution from $1973(\mathrm{BH})$ and $1985(\mathrm{OH})$ onwards. They are available from the Global Surface Summary of the Day (GSOD) of the National Centers for Environmental Information (NCEI; available at: https://www.ncei.noaa.gov; last access: 17 June 2021). Monthly means of AWS daily data are calculated only when at least $90 \%$ of the data are present in the respective month. However, both datasets contain considerable gaps. Therefore, we use data from the European Centre for Medium-Range Weather Forecasts (ECMWF) ERA5 Reanalysis (1979 onwards, spatial resolution: $31 \mathrm{~km}$, temporal resolution: $1 \mathrm{~h}$; available at: https: / / www.ecmwf.int/en/forecasts / datasets/reanalysis-datasets / era5; last access: 16 April 2021) [55]. Monthly ERA5 reanalysis data were extracted from the grid points closest 
to $\mathrm{OH}$ and $\mathrm{BH}$ stations as well as closest to the $\mathrm{OH}-12$ drill site on LCL (Figure 1) through the KNMI Climate Explorer (available at: https:/ / climexp.knmi.nl/; last access: 16 April 2021) [56]. Coordinates and altitudes of the selected ERA5 grid points and the corresponding sites are given in Supplementary Table S1. For the analysis of OH-12 time series, we focus on the following meteorological parameters from the closest ERA5 grid point: precipitation, near-surface and 850 mbar air temperatures, zonal and meridional components of the 850 mbar wind. From the two wind components at 850 mbar geopotential height, which roughly corresponds to the altitude of LCL, we calculated wind directions and derived wind roses for the study site (Equation (S3)).

Data on SIE in the Bellingshausen-Amundsen and Weddell Seas, defined as the sections of the Southern Ocean extending from $130^{\circ} \mathrm{W}-60^{\circ} \mathrm{W}$ and $60^{\circ} \mathrm{W}-20^{\circ} \mathrm{E}$, respectively, were obtained from the National Aeronautics and Space Administration (NASA; available at: https: / / earth.gsfc.nasa.gov / cryo/data/arcticantarctic-sea-ice-time-series; last access: 25 April 2021) [57,58]).

Cross-correlation analyses between OH-12 and ERA5 time series and regional SIE were performed using monthly means. Pearson correlation coefficients $(r)$ and $p$-values $(p)$ were calculated at the $95 \%$ confidence level $(\alpha=0.05)$.

\section{Results}

\subsection{Firn Core Age Model}

Due to the generally high snow accumulation on LCL, the $\mathrm{H}_{2} \mathrm{O}_{2}$ record is well preserved in the OH-12 firn core, showing clear seasonal cycles in the upper $16 \mathrm{~m}$, albeit a pronounced double peak structure (Figure 2). The drill date of OH-12 (14 January 2016) was used as first tie point for deriving the age model. $\mathrm{H}_{2} \mathrm{O}_{2}$ is positively related to accumulation rates and inversely related to temperature, i.e., low accumulation rates and/or higher air and thus snow temperatures favour the degassing of $\mathrm{H}_{2} \mathrm{O}_{2}$ from the snowpack [50,54,59]. Therefore, the minima in summer might be caused by missing snow precipitation and/or higher temperatures. In addition, surface melt can lead to the redistribution of $\mathrm{H}_{2} \mathrm{O}_{2}$ in the snowpack causing a staircase shape of the peaks, which however is not the case in $\mathrm{OH}-12$ above $16 \mathrm{~m}$ depth. Since at the time of the drilling of OH-12 (mid-January 2016), the uppermost double peak had already formed, we set 1 January to the first maximum of the $\mathrm{H}_{2} \mathrm{O}_{2}$ double peak (from the top) for each year identified between $0 \mathrm{~m}$ and $16 \mathrm{~m}$ depth. Below $16 \mathrm{~m}$ depth, the $\mathrm{H}_{2} \mathrm{O}_{2}$ record seems to be altered by melt water percolation leading to a staircase shape of the peak and hence an unclear seasonal cyclicity (Figure 2). The firn core stratigraphy exhibiting several ice layers in this part of the core may provide evidence for surface melt and percolation events (see Section 3.2, Figure 4a). Hence, 1 January was set to the first peak (from the top) that is higher than the mean value of the entire record period $(1.96 \mu \mathrm{M})$ at about $18.2 \mathrm{~m}$ depth (Figure 2$)$. Below that depth, the age scale was derived by linear extrapolation using the depth-age relationship between the previous two clearly identifiable peaks (years 2012 and 2013). In total, $\mathrm{OH}-12$ covers four full years (2012-2015; Figure 2). The estimated dating uncertainty is \pm 2 months above $16 \mathrm{~m}$ depth and increases to \pm 10 months in the bottom part of the core due to the percolation biased $\mathrm{H}_{2} \mathrm{O}_{2}$ record.

To improve the ALC-based age model, we accounted for precipitation intermittency at the study site using ERA5 reanalysis data, since environmental signals are only recorded in the snow when there is a precipitation event [60-62]. First, we tested, how well ERA5 reanalysis data capture the seasonal variability of precipitation in the northern AP region. For this, we compared the ERA5 and AWS precipitation records from $\mathrm{BH}$ and $\mathrm{OH}$ stations on a monthly scale as well as based on the seasonal cycle calculated using the respective overlapping period between both datasets (AWS/ERA5 OH: 1985-2020; AWS/ERA5 BH: 1979-2020). For both stations, correlations are statistically significant and quite high for monthly means ( $r=0.68$ for $\mathrm{BH}, r=0.71$ for $\mathrm{OH}$ with $p<0.05)$ as well as for the seasonal cycle $(r=0.59$ for $\mathrm{BH}, r=0.54$ for $\mathrm{OH}$ with $p=0)$. Hence, we conclude that ERA5 reanalysis data reliably reflect the seasonal variability of synoptic precipitation in the northern AP 
region. However, the influence of the orography on the annual precipitation distribution which is particularly important on LCL is not fully captured by ERA5. Furthermore, the ERA5 precipitation record comprises both solid and liquid precipitation, with the latter not contributing to accumulation on LCL. Finally, wind-driven removal and relocation of freshly fallen snow can partially alter the annual accumulation distribution at the site. Despite these biases, the age model of $\mathrm{OH}-12$ can be improved by considering the annual precipitation distribution from the ERA5 grid point closest to the firn core drill site to best represent the annual accumulation distribution on LCL. Based on this, we calculated for each single year covered by $\mathrm{OH}-12$ the percentage of each month in annual precipitation. Subsequently, the thickness of each annual layer was calculated and multiplied by the monthly percentage precipitation shares in the respective year. Hence, for each year, we obtained the monthly layer thicknesses and thus could derive a depth-age relationship. The age of firn core samples within each monthly layer could then be computed by linear interpolation. The precipitation-based weighted age scale is slightly shifted compared to the ALC-based age scale depending on the core section (maximum offset: 33 days; Figure 3). In the following, we use the precipitation-based weighted age scale for the construction of $\mathrm{OH}-12$ time series and subsequent statistical analyses.

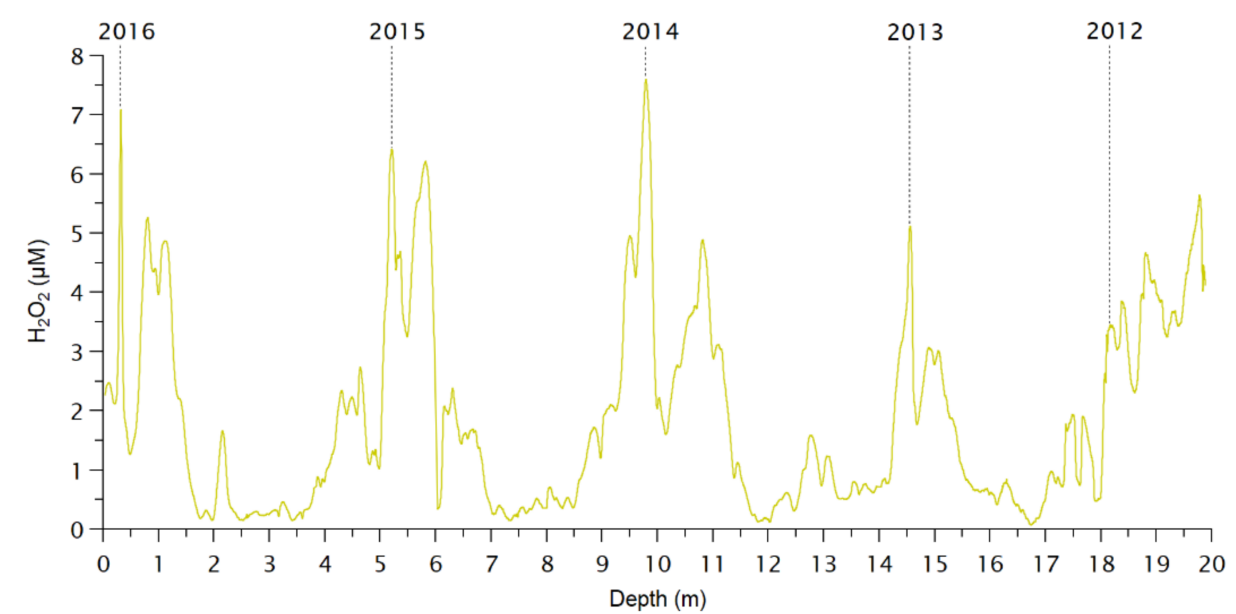

Figure 2. Age-scale construction of firn core OH-12 by counting annual layers in the CFA-derived, high-resolution $\mathrm{H}_{2} \mathrm{O}_{2}$ profile. Details are explained in the text.



Figure 3. Comparison of the weighted age scale (coloured lines) of firn core OH-12 with the ALC-based (unweighted) age scale (grey lines) for (a) $\delta^{18} \mathrm{O}$ and (b) d excess. 


\subsection{Firn Core Stratigraphy and Accumulation Rates}

The high-resolution density-depth profile of OH-12 (Figure 4a) shows a clear increase in density with depth reflecting snow compaction processes and the metamorphosis from snow to firn. Linear regression across the entire density-depth profile reveals the snow-firn density transition $\left(550 \mathrm{~kg} \mathrm{~m}^{-3}\right)$ at about $8.4 \mathrm{~m}$ depth. Furthermore, firn core $\mathrm{OH}-12$ is characterised by the presence of numerous ice lenses and layers with thicknesses varying between $0.6 \mathrm{~mm}$ and $40 \mathrm{~mm}$. This is also visible in the high-resolution density-depth profile that exhibits distinct maxima $\left(\geq 800 \mathrm{~kg} \mathrm{~m}^{-3}\right)$ with values up to the density of pure ice $\left(917 \mathrm{~kg} \mathrm{~m}^{-3}\right)$ in the respective core sections (Figure $\left.4 \mathrm{a}\right)$. More than $75 \%$ of all ice lenses and layers have a width of $<10 \mathrm{~mm}$. Most of them are probably not related to surface melt, but instead are formed by wind ablation and wind scouring processes or infiltration, percolation and refreezing of liquid precipitation. In addition, hoar frost formation on the snow surface also plays a role. Hoar frost layers in OH-12 are between $2 \mathrm{~mm}$ and $25 \mathrm{~mm}$ thick. In order to analyse the firn core stratigraphy for the occurrence of surface melt events, we only consider ice layers most likely indicating melt, i.e., near-horizontal ice layers with a continuous lateral extension and little or no air bubbles [63,64]. They vary between $1 \mathrm{~mm}$ and $40 \mathrm{~mm}$ in thickness with a mean value of $8.5 \mathrm{~mm}$ (Figure $4 \mathrm{~b}$ ). The detailed thickness distribution of the melt layers is shown in Supplementary Figure S1. Most prominent melt layers are found at $3.8 \mathrm{~m}(39 \mathrm{~mm}), 4.9 \mathrm{~m}(35 \mathrm{~mm})$ and $13.5 \mathrm{~m}$ depth $(40 \mathrm{~mm})$ corresponding to April/May 2015, February 2015 and April 2013, respectively (Figure 4a,b).

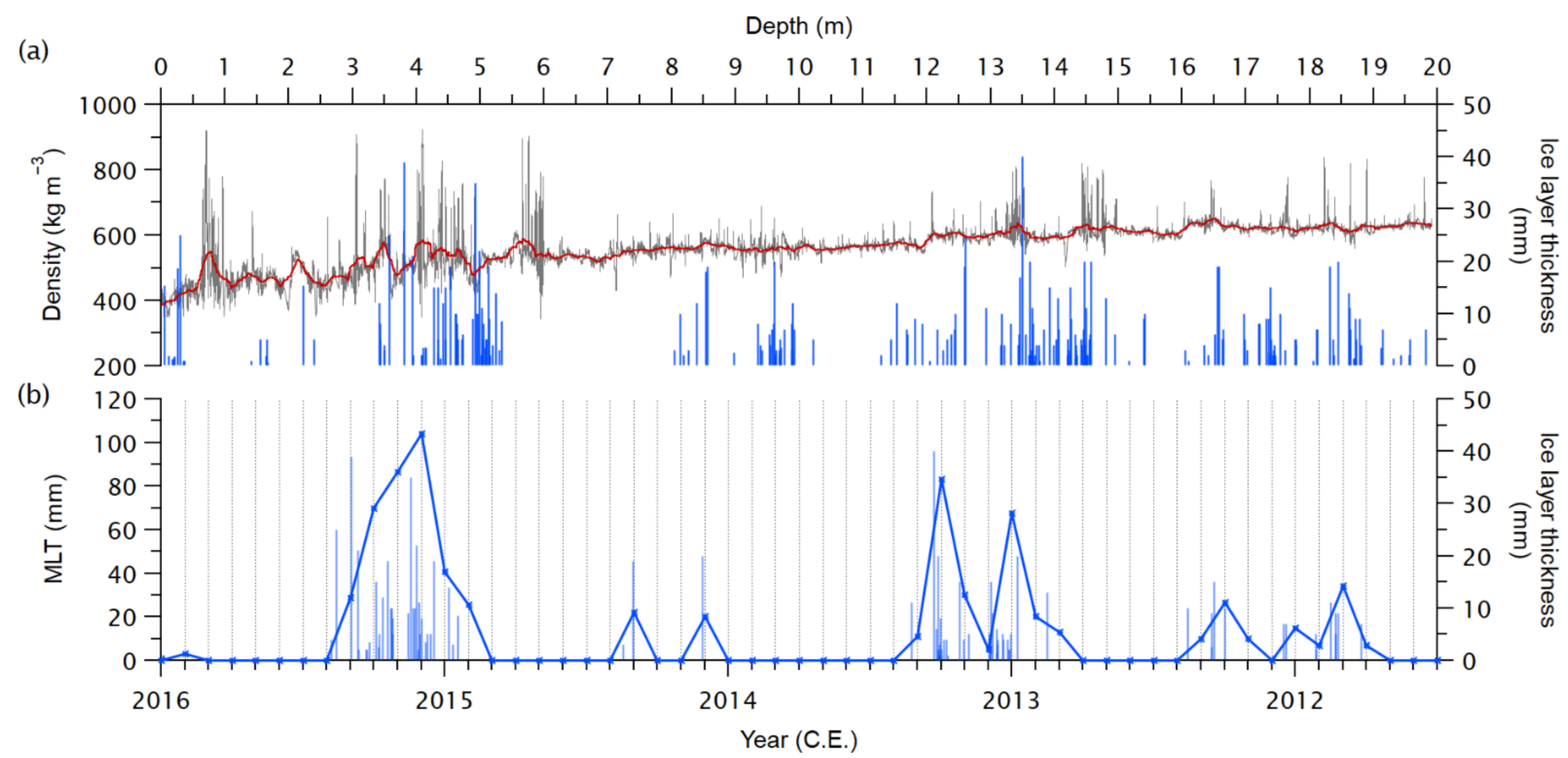

Figure 4. (a) Ice layer stratigraphy (blue lines) and high-resolution density-depth profile (grey; 1500-point running mean in red) of firn core OH-12. (b) Total monthly melt layer thickness (MLT; bold blue line) for the period covered by OH-12 calculated from ice layers indicating surface melt (light blue lines; details in the text) using the weighted age scale.

Based on the identified melt layers and the weighted age scale, the total melt layer thickness (MLT) was calculated for each month within the period covered by $\mathrm{OH}-12$ (Figure $4 \mathrm{~b}$ ), revealing a clear seasonality with MLT maxima occurring during summer and MLT minima during winter months. The years 2013 and 2015 show the highest MLT values reaching up to $83 \mathrm{~mm}$ and $104 \mathrm{~mm}$ in austral late summers 2013 and 2015, indicating strong surface melt processes at the $\mathrm{OH}-12$ drill site (Figure $4 \mathrm{~b}$ ). Based on the high-resolution density measurements of $\mathrm{OH}-12$, snow accumulation at the study site was calculated for each full year identified in the core (Table 1). On average, snow accumulation amounts to about $2500 \mathrm{~kg} \mathrm{~m}^{-2} \mathrm{a}^{-1}$ with only little variations for the period 2012-2015 (on average 
$\pm 8 \%$; Table 1). The maximum accumulation rate is observed in $2013\left(2890 \mathrm{~kg} \mathrm{~m}^{-2} \mathrm{a}^{-1}\right)$, whereas the minimum value is reached in $2015\left(2260 \mathrm{~kg} \mathrm{~m}^{-2} \mathrm{a}^{-1}\right)$.

Table 1. Annual accumulation rates calculated for the OH-12 drill site for the period 2012-2015.

\begin{tabular}{|c|c|}
\hline Year & Accumulation Rate $\left(\mathrm{kg} \mathrm{m}^{-2} \mathrm{a}^{-1}\right)$ \\
\hline 2012 & 2260 \\
\hline 2013 & 2470 \\
\hline 2014 & 2890 \\
\hline 2015 & 2390 \\
\hline 2012-2015 & 2500 \\
\hline
\end{tabular}

3.3. Firn Core Records of Black Carbon (BC), Non-Sea-Salt Sulphur (nssS) and the Non-Sea-Salt Sulphur-Sea-Salt Sodium Ratio (nssS/ssNa)

The high-resolution depth profiles of BC, nssS and nssS/ssNa exhibit distinct maxima at certain depths (Figure 5). BC reaches maximum values of $11.6 \mathrm{ng} \mathrm{g}^{-1}$ and $12.7 \mathrm{ng} \mathrm{g}^{-1}$ at $3.3 \mathrm{~m}$ (May/June 2015) and $16.5 \mathrm{~m}$ depth (June/July 2012), which are more than 20 times higher compared to the mean value of $0.5 \mathrm{ng} \mathrm{g}^{-1}$ (Figure 5a). The combined analysis of the nssS and nssS/ssNa records reveals three remarkable maxima compared to the mean values of $18.6 \mathrm{ng} \mathrm{g}^{-1}$ and 0.06 , respectively (calculated excluding negative values): a single peak at about $3.3 \mathrm{~m}$ depth (May/June 2015; nssS: $72.2 \mathrm{ng} \mathrm{g}^{-1}$; nssS/ssNa: 1.2) that coincides with the first BC maximum (from the top), a double peak between 9.3-10.1 m depth (November 2013-March 2014; maximum nssS: $71.2 \mathrm{ng} \mathrm{g}^{-1}$; maximum nssS/ssNa: 0.95) and a long-stretched peak between 16.9-18.5 m depth (November 2011-May 2012; maximum nssS: $86.9 \mathrm{ng} \mathrm{g}^{-1}$; maximum nssS/ssNa: 0.4; Figure 5b). The maxima in the $\mathrm{BC}$, nssS and nssS/ssNa records point towards cross-regional environmental events which left an imprint on the LCL ice cap and can thus be used as independent tie points for confirming the weighted age scale of $\mathrm{OH}-12$ (see Section 4.1).

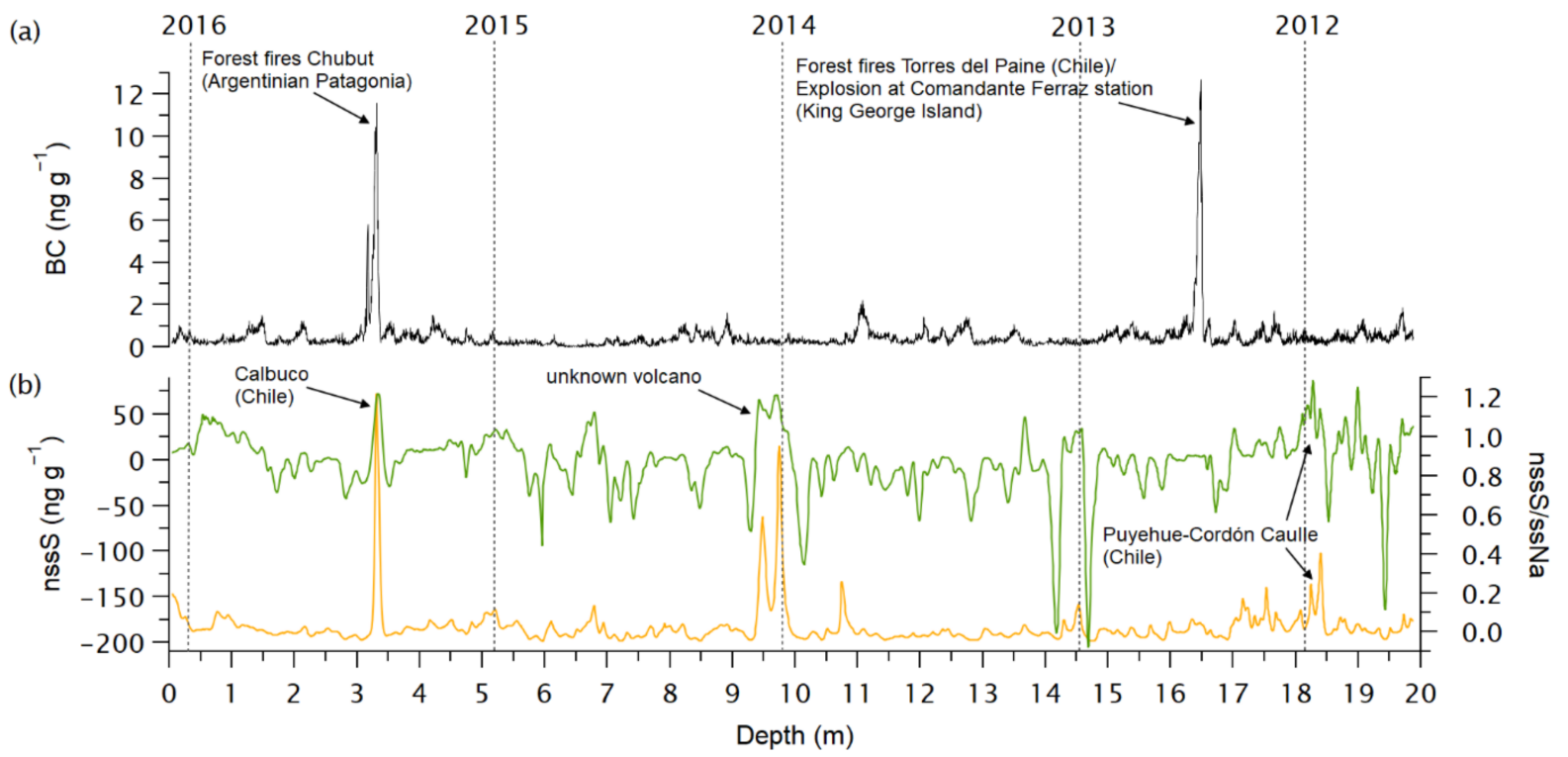

Figure 5. High-resolution depth profiles of (a) BC (black), (b) non-sea-salt sulphur (nssS; green) and the non-sea-salt sulphur-sea-salt sodium ratio (nssS/ssNa; orange) of firn core OH-12. Southern hemispheric events assigned to the remarkable maxima identified in the BC, nssS and nssS/ssNa records are indicated (for details, see Section 4.1).

\subsection{Firn Core and Precipitation Stable Water Isotopes}

In general, within each collection period (Table 2), the precipitation samples are well distributed over the recorded years, i.e., there is more than one sample for each month (Supplementary Figure S2). Altogether, the three sampling periods cover 49 months, with 
each month sampled four times except March, which was sampled five times. However, as described in Section 2.1 and by Fernandoy et al. [31]. Several samples had to be excluded from the statistical analysis of stable water isotope data (Supplementary Figure S2). Accordingly, Figure 6a shows the stable water isotope composition of all considered precipitation samples collected at $\mathrm{OH}$ station between 2008 and 2017 in comparison to the stable water isotope composition of $\mathrm{OH}-12$. The stable water isotope composition of the 2015-2017 precipitation samples is very similar to that of the previously collected samples although covering a wider range (from $-22.1 \%$ to $-0.9 \%$ for $\delta^{18} \mathrm{O}$ and from $-181.6 \%$ to $-11.8 \%$ for $\delta \mathrm{D}$; Table 2). The $2015-2017$ samples have mean $\delta^{18} \mathrm{O}$ and $\delta \mathrm{D}$ values of $-9.2 \%$ and $-74.5 \%$, respectively, and a mean d excess of $-1.0 \%$. Mean $\delta^{18} \mathrm{O}, \delta \mathrm{D}$ and d excess values of all precipitation samples collected between 2008 and $2017(n=294)$ amount to $-9.4 \%,-74.4 \%$ and $0.8 \%$, respectively. Based on all precipitation samples, a better constrained LMWL has been calculated for the study site: $\delta \mathrm{D}=7.76 \times \delta^{18} \mathrm{O}-1.52$ $\left(R^{2}=0.97, p=0\right.$; Figure 6a).

Table 2. Basic statistics of the stable water isotope composition of precipitation samples collected at Bernardo O'Higgins station from January 2008 to March 2009, from March to November 2014 and from December 2015 to December 2017. For each sampling period the number of samples $(n)$ considered for the statistical analysis together with the total number of collected samples (in brackets) is given.

\begin{tabular}{|c|c|c|c|c|c|c|c|c|c|c|c|c|}
\hline $\begin{array}{c}\text { Sampling } \\
\text { Period }\end{array}$ & \multicolumn{3}{|c|}{$\begin{array}{l}\text { 01/2008-03/2009 } \\
\text { (15 Months) }\end{array}$} & \multicolumn{3}{|c|}{$\begin{array}{l}\text { 03/2014-11/2014 } \\
\text { (9 Months) }\end{array}$} & \multicolumn{3}{|c|}{$\begin{array}{c}\text { 12/2015-12/2017 } \\
\text { (25 Months) }\end{array}$} & \multicolumn{3}{|c|}{$\begin{array}{c}2008-2017 \\
\text { (49 Months) }\end{array}$} \\
\hline$n$ (samples) & \multicolumn{3}{|c|}{139 (139) } & \multicolumn{3}{|c|}{$72(94)$} & \multicolumn{3}{|c|}{$83(133)$} & \multicolumn{3}{|c|}{$294(366)$} \\
\hline Stable water isotope & $\delta^{18} \mathrm{O}$ & $\delta \mathrm{D}$ & d excess & $\delta^{18} \mathrm{O}$ & $\delta \mathrm{D}$ & d excess & $\delta^{18} \mathrm{O}$ & $\delta \mathrm{D}$ & d excess & $\delta^{18} \mathrm{O}$ & $\delta \mathrm{D}$ & d excess \\
\hline composition & $(\%)$ & $(\%)$ & (\%o) & $(\%)$ & $(\%$ o $)$ & (\%o) & $(\%)$ & $(\%)$ & $(\%)$ & $(\%)$ & $(\%$ o $)$ & $(\%$ ) \\
\hline Min & -19.4 & -150.6 & -6.6 & -18.4 & -148.4 & -8.9 & -22.1 & -181.6 & -9.8 & -22.1 & -181.6 & -9.8 \\
\hline Mean & -9.2 & -70.5 & 2.7 & -10.1 & -81.9 & -0.9 & -9.2 & -74.5 & -1.0 & -9.4 & -74.4 & 0.8 \\
\hline Max & -3.8 & -21.8 & 22.3 & -1.3 & -16.0 & 13.3 & -0.9 & -11.8 & 22.4 & -0.9 & -11.8 & 22.4 \\
\hline Sdev & 3.3 & 26.4 & 4.2 & 4.4 & 34.2 & 5.7 & 4.3 & 33.4 & 5.7 & 3.9 & 30.8 & 5.3 \\
\hline
\end{tabular}

(a)

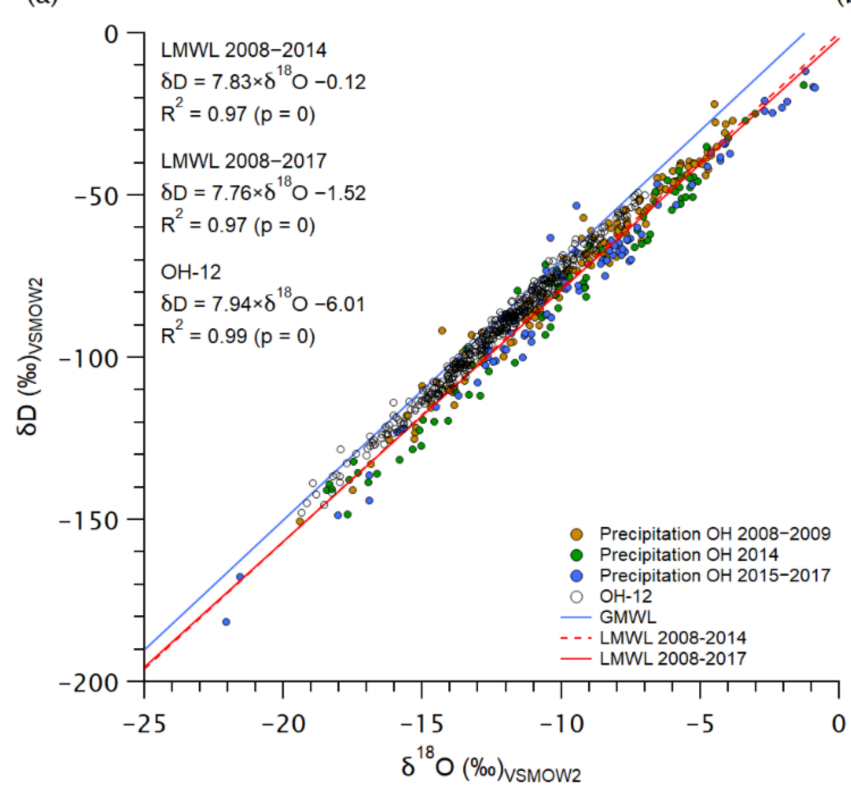

(b)

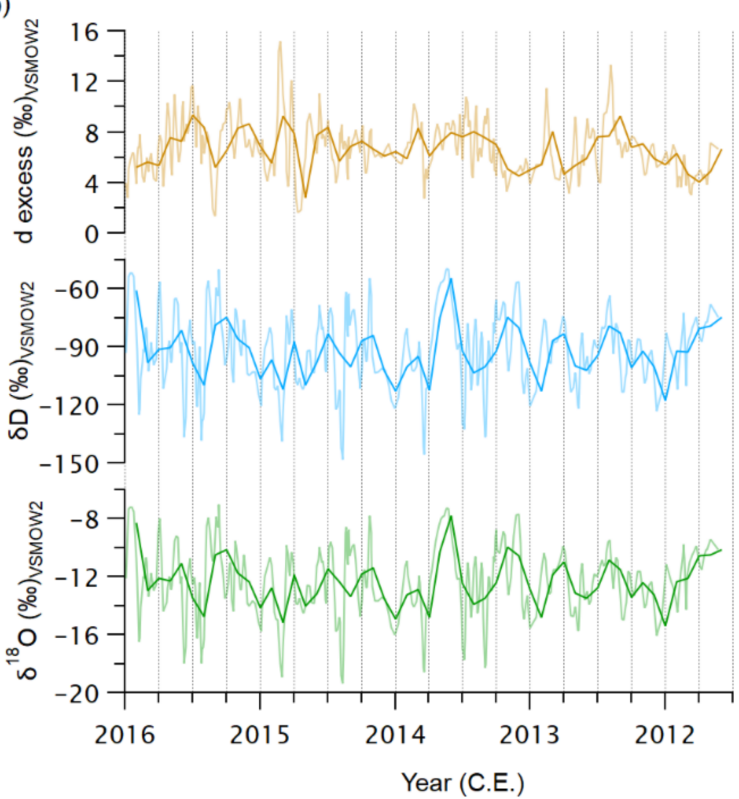

Figure 6. (a) $\delta^{18} \mathrm{O}-\delta \mathrm{D}$ relationship of all considered precipitation samples collected at Bernardo $\mathrm{O}^{\prime} \mathrm{Higgins}$ station $(\mathrm{OH})$ between 2008 and 2017 ( $n=294$; coloured dots) compared to the $\delta^{18} \mathrm{O}-\delta \mathrm{D}$ relationship of firn core OH-12 $(n=414$; white dots). The Global Meteoric Water Line (GMWL) is indicated in blue. The Local Meteoric Water Line (LMWL) established for the study site by Fernandoy et al. [31,32] is shown as a dashed red line and the LMWL derived in this study as a solid red line. For each $\delta^{18} \mathrm{O}-\delta \mathrm{D}$ relationship, the equation, the coefficient of determination $\left(\mathrm{R}^{2}\right)$ and the $p$-value $(p)$ are given. (b) Time series of $\delta^{18} \mathrm{O}, \delta \mathrm{D}$ and d excess of $\mathrm{OH}-12$ constructed based on the weighted age scale. High-resolution data are shown as light-coloured lines and monthly means as bold lines. 
Stable oxygen and hydrogen isotopes of OH-12 are highly correlated $\left(\mathrm{R}^{2}=0.99, p=0\right.$; Figure 6a). The slope of the $\delta^{18} \mathrm{O}-\delta \mathrm{D}$ relationship (7.94) is close to that of the Global Meteoric Water Line (GMWL) [49] and is of the same order of magnitude as the slope of the site-specific LMWL $(\mathrm{m}=7.76)$. However, intercepts differ significantly $(\mathrm{OH}-12$ : -6.01 ; LMWL: -1.52 ; GMWL: +10), which is also reflected by the position of the OH-12 samples in the $\delta^{18} \mathrm{O}-\delta \mathrm{D}$ plot (Figure 6a). All firn core samples are located above the LMWL and mostly below the GMWL, implying higher d excess values compared to the event-based precipitation samples from $\mathrm{OH}$ station.

$\delta^{18} \mathrm{O}$ and $\delta \mathrm{D}$ values show a high sub-annual variability ranging between $-7.0 \%$ and $-19.4 \%$ and between $-49.3 \%$ and $-148.0 \%$, respectively (Table 3 ). Mean $\delta^{18} \mathrm{O}$ and $\delta \mathrm{D}$ values for the period covered by $\mathrm{OH}-12$ are $-12.4 \%$ and $-92.0 \%$, respectively. D excess values vary between $1.4 \%$ and $15.2 \%$ with a mean value of $6.8 \%$ (Figure $6 \mathrm{~b}$ and Table 3 ). Inter-annual differences in the stable water isotope composition of OH-12 (Table 4) are less pronounced than those on the sub-annual timescale. However, the year 2015, which contains thick ice layers, exhibits slightly higher mean annual $\delta$ values than the other years. In contrast, this is not the case for the year 2013, despite the presence of exceptionally thick ice layers. Differences in the mean annual d excess are negligible between the four years.

Table 3. Basic statistics of the stable water isotope composition of firn core OH-12 $(n=414)$.

\begin{tabular}{cccc}
\hline & $\boldsymbol{\delta}^{\mathbf{1 8}} \mathbf{O} \mathbf{( \% )}$ & $\boldsymbol{\delta} \mathbf{D}(\% \mathbf{)}$ & d Excess (\%o) \\
\hline Min & -19.4 & -148.0 & 1.4 \\
Mean & -12.4 & -92.0 & 6.8 \\
Max & -7.0 & -49.3 & 15.2 \\
Sdev & 2.4 & 19.2 & 2.1 \\
\hline
\end{tabular}

Table 4. Annual minimum, mean and maximum values and standard deviations of stable water isotopes of firn core $\mathrm{OH}-12$ for the period 2012-2015 (January-December) calculated based on the weighted age scale.

\begin{tabular}{|c|c|c|c|c|c|c|c|c|c|c|c|c|}
\hline \multirow[t]{2}{*}{ Year } & \multicolumn{3}{|c|}{2012} & \multicolumn{3}{|c|}{2013} & \multicolumn{3}{|c|}{2014} & \multicolumn{3}{|c|}{2015} \\
\hline & $\begin{array}{l}\delta^{18} \mathrm{O} \\
(\% \mathrm{o})\end{array}$ & $\delta \mathrm{D}(\%$ o $)$ & $\begin{array}{c}\mathrm{d} \text { excess } \\
(\% o)\end{array}$ & $\begin{array}{l}\delta^{18} \mathrm{O} \\
(\% \mathrm{o})\end{array}$ & $\delta \mathrm{D}(\%$ o $)$ & $\begin{array}{c}\mathrm{d} \text { excess } \\
(\% \mathrm{o})\end{array}$ & $\begin{array}{l}\delta^{18} \mathrm{O} \\
(\% \mathrm{o})\end{array}$ & $\delta \mathrm{D}(\%$ o $)$ & $\begin{array}{c}\mathrm{d} \text { excess } \\
(\% \mathrm{o})\end{array}$ & $\begin{array}{l}\delta^{18} \mathrm{O} \\
(\% \mathrm{o})\end{array}$ & $\delta \mathrm{D}(\%$ o $)$ & $\begin{array}{c}\mathrm{d} \text { excess } \\
(\% \mathrm{o})\end{array}$ \\
\hline Min & -16.0 & -123.1 & 3.2 & -18.5 & -145.5 & 2.7 & -19.4 & -148.0 & 1.6 & -18.0 & -138.4 & 1.4 \\
\hline Mean & -12.5 & -92.8 & 6.9 & -12.4 & -92.4 & 6.9 & -12.7 & -95.0 & 7.0 & -12.0 & -89.0 & 7.1 \\
\hline Max & -9.5 & -63.6 & 13.3 & -7.2 & -49.3 & 10.8 & -7.8 & -54.3 & 15.2 & -7.0 & -49.9 & 11.7 \\
\hline Sdev & 1.5 & 13.0 & 2.1 & 2.8 & 22.5 & 1.9 & 2.5 & 20.2 & 2.4 & 5.4 & 39.8 & 3.3 \\
\hline
\end{tabular}

\subsection{Cross-Correlation Analysis}

For cross-correlation analysis between OH-12 time series and ERA5 near-surface air temperature at LCL, we first compared the ERA5 and AWS temperature records from $\mathrm{BH}$ and $\mathrm{OH}$ stations. For both stations, the records are highly and statistically significantly correlated on a monthly scale as well as with respect to the seasonal cycle calculated as previously described (see Section 3.1; $r \geq 0.9, p<0.001$ for $\mathrm{BH}$ and $\mathrm{OH}$ ). Hence, we consider ERA5 reanalysis data to reliably reflect the regional temperature variability. We accounted for the elevation difference between the OH-12 drill site and the closest ERA5 grid point $(\Delta \mathrm{h}=812 \mathrm{~m}$; Supplementary Table S1) by calculating a monthly lapse rate using the ERA5 records of near-surface and 850 mbar air temperature. Cross-correlations were calculated based on monthly means considering only the period with full-year records for OH-12 (2012-2015; Table 5). Monthly means of OH-12 were computed using the weighted age scale.

$\delta^{18} \mathrm{O}$ and $\delta \mathrm{D}$ values of $\mathrm{OH}-12$ are not related to ERA5 near-surface air temperatures at LCL (Table 5). Instead, statistically significant correlations with ERA5 temperatures exist for both d excess and MLT (d excess: $r=-0.4, p<0.01$; MLT: $r=0.5, p<0.0001$ ). Furthermore, $\delta^{18} \mathrm{O}$ and $\delta \mathrm{D}$ values of $\mathrm{OH}-12$ are highly inter-correlated $(r>0.99, p=0)$, but both show no negative relation to the d excess (Table 5). Monthly MLT is neither correlated with $\delta^{18} \mathrm{O}$ or $\delta \mathrm{D}$, nor with the d excess. Moreover, there is no relationship of $\delta^{18} \mathrm{O}, \delta \mathrm{D}$ and $\mathrm{d}$ excess with SIE in the close-by Bellingshausen-Amundsen and Weddell Seas for the period 
2012-2015 (Table 5). Instead, we found a statistically significant negative correlation of MLT with SIE in both sectors $(r=-0.6, p=0)$.

Table 5. Results of cross-correlation analysis for monthly records of $\delta^{18} \mathrm{O}, \delta \mathrm{D}$, $\mathrm{d}$ excess and total melt layer thickness (MLT) of firn core OH-12 and monthly time series of ERA5 near-surface air temperature at Plateau Laclavere, sea ice extent (SIE) in the Bellingshausen-Amundsen (BA) and Weddell Seas (Weddell). Prominent correlations with a low $p$-value $(p<0.01, \alpha=0.05)$ are marked bold.

\begin{tabular}{|c|c|c|c|c|c|c|}
\hline & $\delta^{18} \mathrm{O}$ & $\delta \mathrm{D}$ & d Excess & $\mathrm{T}_{\text {mean }}$ ERA5 & SIE BA & SIE Weddell \\
\hline MLT & & & & & & \\
\hline$r$ & 0.07 & 0.07 & 0.04 & 0.53 & -0.59 & -0.56 \\
\hline $\begin{array}{c}p \\
\delta^{18} \mathrm{O}\end{array}$ & 0.66 & 0.64 & 0.77 & 0.0001 & 0 & 0 \\
\hline$r$ & 1 & 0.99 & -0.03 & 0.06 & 0.03 & 0.02 \\
\hline $\begin{array}{c}p \\
\delta \mathrm{D}\end{array}$ & 0 & 0 & 0.86 & 0.67 & 0.85 & 0.91 \\
\hline$r$ & & 1 & 0.08 & 0.02 & 0.05 & 0.03 \\
\hline $\begin{array}{c}p \\
\text { d excess }\end{array}$ & & 0 & 0.59 & 0.88 & 0.75 & 0.85 \\
\hline$r$ & & & 1 & -0.38 & 0.18 & 0.10 \\
\hline$p$ & & & 0 & 0.01 & 0.21 & 0.52 \\
\hline
\end{tabular}

\section{Discussion}

\subsection{Environmental Signals Recorded in Firn Core $\mathrm{OH}-12$}

$\mathrm{OH}-12$ is the first firn core from LCL with available high-resolution glacio-chemical data. Hence, for the first time, it is possible to assess whether and how signals of atmospheric emissions such as from volcanic eruptions, biomass burning and anthropogenic pollution are recorded and preserved in an ice cap on the northern AP. We consider the distinct maxima identified in the records of $\mathrm{BC}$, nssS and nssS/ssNa to be real, since we did not find clear coincidences between enhanced concentrations of BC, nssS and nssS/ssNa and remarkable maxima in the high-resolution depth records of density and ice (melt) layer thickness (Figure 7). However, in case of vertical movement of these chemical species due to meltwater percolation, the impact on the timing of the peaks found in their depth profiles would likely be diminished by the very high annual snow accumulation on LCL.

In the nssS and nssS/ssNa records, three distinct maxima were identified, two of which could be assigned to well-known volcanic eruptions in the Southern Hemisphere. The long-stretched peak of medium-high amplitude at about 16.9-18.5 m depth likely reflects the Volcanic Explosivity Index (VEI) 5 eruption of the Puyehue-Cordón Caulle volcano in Southern Chile (June 2011-April 2012) [65]. Koffman et al. [66] found sulphate and ash from this event in surface snow and shallow firn core samples from the West Antarctic Ice Sheet (WAIS) Divide region. According to Koffman et al. [66], the ash cloud of the Puyehue-Cordón Caulle eruption circled the globe between $40^{\circ} \mathrm{S}$ and $60^{\circ} \mathrm{S}$ four times from 4 June to 20 July 2011, transporting ash and sulphate primarily with the westerlies rapidly to Antarctica. Hence, it is very likely that sulphate deposition also took place on the LCL ice cap, although the sulphate peak in OH-12 does not occur directly in austral winter 2011, as observed on the WAIS Divide [66], but rather in austral spring and summer 2011/2012. This may be due to the relatively high dating uncertainty in the lower part of the firn core. Differently to explosive stratospheric eruptions, the Puyehue-Cordón Caulle eruption did not cause a sustained deposition of aerosols (i.e., over 1-3 years), but transport and deposition of ash and sulphate primarily occurred through the troposphere and were constrained to the $\sim 2-3$ weeks following the eruption [66]. This also suggests that the nssS and nssS/ssNa maxima at 9.3-10.1 m depth (austral summer 2013/2014) in OH-12 are not related to the Puyehue-Cordón Caulle eruption.

Long-range transport of volcanic aerosols in the Southern Hemisphere also was observed after the Calbuco VEI 4 eruption in Southern Chile in April 2015 [67-69] that resulted in a record size of the ozone hole over Antarctica in October 2015 [70]. The volcanic aerosol 
plume of Calbuco was mainly advected eastward in the Southern Hemisphere (across northeastern South America and South Africa) latitudinally bounded by the subtropical barrier and the polar vortex, but potentially reached polar latitudes about 4 months after the eruption $\left(60^{\circ} \mathrm{S}\right)[67,68]$. Fernandoy et al. [31] showed that LCL clearly has been influenced by air masses originating over the South American continent during the preceding years 2008-2014. Hence, we infer that the nssS and nssS/ssNa maxima in OH-12 at about $3.3 \mathrm{~m}$ depth are connected to the Calbuco eruption. However, further confirmation of the eruption sources will require microphysical investigations of the respective core sections.

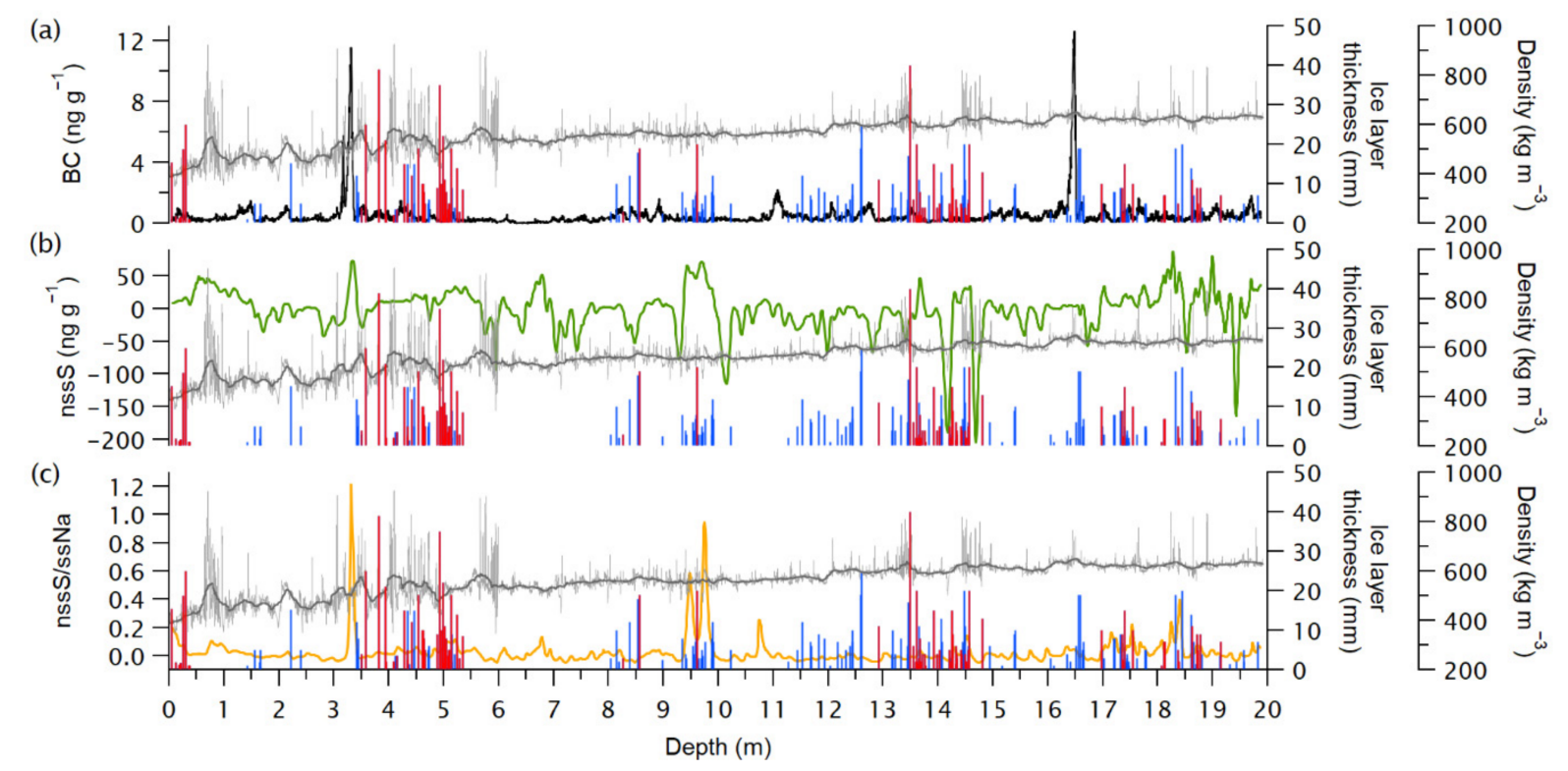

Figure 7. Comparison of $\mathrm{OH}-12$ high-resolution depth records of (a) black carbon (BC; black), (b) non-sea-salt sulphur (nssS; green) and (c) the non-sea-salt sulphur-sea-salt sodium ratio (nssS/ssNa; orange) with the high-resolution density-depth profile (grey; 1500-point running mean in bold) and the ice layer stratigraphy (blue). Ice layers indicating surface melt are highlighted in red.

Attributing the origin of the exceptionally high $\mathrm{BC}$ peaks at about $3.3 \mathrm{~m}$ and $16.5 \mathrm{~m}$ depth in OH-12 is challenging (Figure 5a). The explosion at the Brazilian Antarctic station Comandante Ferraz (CF), located in Admiralty Bay on King George Island (Figure 1a), on 25 February 2012 could have caused or contributed to the distinct BC maximum at $16.5 \mathrm{~m}$ depth. According to Evangelista et al. [71], the $450 \mathrm{~m}$ high plume of smoke rapidly dispersed in NE-E direction travelling over King George Island before reaching the Drake Channel and passing the northern tip of the AP. Hence, the Comandante Ferraz fire seems a probable source for the deposition of BC on the LCL ice cap. Furthermore, vast South American forest fires could be a major ash source for the two BC peaks in OH-12. Generally, (tropical) biomass burning is the main source of atmospheric BC in Antarctica [72]. Several studies have shown that emissions from biomass burning in (tropical) South America reached as far as to the northern AP [73] and Dronning Maud Land [74]. Most recently, Jumelet et al. [75] provided evidence that biomass burning events are capable of injecting significant amounts of BC particles up to the lower stratosphere from where they can be transported towards higher latitudes. Hence, the vast forest fires in Torres del Paine in southern Chile, which lasted from the end of December 2011 until March 2012, could have contributed to the BC peak at $16.5 \mathrm{~m}$ depth. The BC maximum at $3.3 \mathrm{~m}$ depth coincides almost exactly with the nssS and nssS/ssNa peaks of the Calbuco eruption. It has likely been caused by BC emitted from forest fires, which took place in the Argentinian province Chubut (Patagonia) between mid-February and the beginning of April 2015, i.e., at the time of the Calbuco eruption. Both forest fires, in Torres del Paine in 2011/12 and in Argentinian Patagonia in 2015, are among the most devastating forest fires documented in these regions [76-78] and hence, are likely to have left an imprint on the LCL ice cap. 
However, other BC sources than biomass burning such as industrial emissions cannot be ruled out to have contributed to the deposition of BC on the LCL ice cap. Recent model simulations show that emissions from fossil fuels and biofuels account for more than $70 \%$ of the BC deposition over James Ross Island in the present day [79].

In summary, the environmental signals found in the glacio-chemical records of $\mathrm{OH}-12$ provide clear evidence for a connection between the northern AP and the South American continent.

\subsection{Accumulation Rates}

Annual snow accumulation rates (Table 1) derived from $\mathrm{OH}-12$ are in line with previous accumulation estimates made by Fernandoy et al. [32] for the same site for 2008 and 2009. However, for the period 2010-2014, Fernandoy et al. [31] reported remarkably (i.e., up to $1800 \mathrm{~kg} \mathrm{~m}^{-2} \mathrm{a}^{-1}$ ) lower accumulation rates than obtained from $\mathrm{OH}-12$ for the period 2012-2015. Furthermore, the mean snow accumulation rate calculated from OH-12 for 2012-2015 (2500 $\left.\mathrm{kg} \mathrm{m}^{-2} \mathrm{a}^{-1}\right)$ is about $700 \mathrm{~kg} \mathrm{~m}^{-2} \mathrm{a}^{-1}$ higher than that estimated for 2008-2014 (1770 $\left.\mathrm{kg} \mathrm{m}^{-2} \mathrm{a}^{-1}\right)$ [31]. We propose that the differences in annual snow accumulation between our study and Fernandoy et al.'s [31] originate from the different dating approaches used.

Fernandoy et al. [32] applied ALC to firn core d excess records as they show a clear seasonal cyclicity in 2008-2009. However, from 2010 onwards, a clear seasonal cyclicity has been neither found in the $\delta$ values nor in the $d$ excess records of LCL firn cores. Therefore, Fernandoy et al. [31] matched measured firn core $d$ excess data to $d$ excess data synthetically derived from meteorological observations by comparing both datasets for similarities in their seasonal variability. Since we consider the $\mathrm{H}_{2} \mathrm{O}_{2}$-based age model of $\mathrm{OH}-12$ to be better constrained, we assume the firn core age model of Fernandoy et al. [31] to have a dating error of +1 year, leading to a substantial underestimation of the annual snow accumulation between 2010 and 2014. We did not find any considerable changes in precipitation amounts during the period 2008-2015 in the AWS and ERA5 precipitation records of $\mathrm{BH}$ and $\mathrm{OH}$ stations and the $\mathrm{OH}-12$ drill position that could explain the remarkably lower snow accumulation on LCL in the years 2010-2014. In the context of generally high accumulation rates, also no evidence for increased wind drift and thus enhanced removal and relocation of snow at the study site during 2008-2015 has been found in the ERA5 record of 850 mbar wind speed for the $\mathrm{OH}-12$ drill position. In summary, we conclude a constantly high annual snow accumulation of about $2500 \mathrm{~kg} \mathrm{~m}^{-2} \mathrm{a}^{-1}$ on $\mathrm{LCL}$ as derived from $\mathrm{OH}-12$ to be realistic.

\subsection{Comparison of Precipitation and Firn Core Stable Water Isotopes}

Generally, precipitation reaching LCL exhibits a lighter stable water isotope composition and higher $\mathrm{d}$ excess values than precipitation at sea level from $\mathrm{OH}$ station (Tables 2 and 3). On average, for 2014-the only year with continuous records for both $\mathrm{OH}$ precipitation (12 $\mathrm{m}$ a.s.1.) and $\mathrm{OH}-12$ (1090 $\mathrm{m}$ a.s.1.) $-\delta^{18} \mathrm{O}$ values of $\mathrm{OH}-12$ are about $2.6 \%$ ( $\delta \mathrm{D}$ about $13 \%$ ) lower than those of event-based precipitation (Tables 2 and 3$)$. This is in line with Fernandoy et al. [31] who found a seasonally varying $\delta^{18} \mathrm{O}$-altitude gradient between $\mathrm{OH}$ station and LCL of up to $-2.4 \% \mathrm{~km}^{-1}$. D excess values of $\mathrm{OH}-12$ are about $8 \%$ o higher than those of $\mathrm{OH}$ precipitation. Furthermore, stable water isotope records of $\mathrm{OH}-12$ show a lower temporal variability compared to $\mathrm{OH}$ precipitation (Supplementary Figure S3). However, in general, there is only little correspondence between both records. The observed differences are likely caused by several processes. First, the orographic effect, i.e., the uplift of air masses from sea level to about $1100 \mathrm{~m}$ altitude, facilitates the fallout of the heavier stable water isotopes near the coast and during transport to the plateau ("altitude effect") $[45,80]$ and hence can partly explain the lower $\delta^{18} \mathrm{O}$ and $\delta \mathrm{D}$ values in the firn core.

Second, post-depositional processes, such as diffusion, wind-pumping, sublimation, melting and refreezing, might alter the stable water isotope composition of the snowpack. Due to the very high accumulation rates at the study site, the exposition time of 
freshly fallen snow to the atmosphere is limited. Hence, diffusion is considered to play only a minor role, also because of the inhibiting effect of the ice layers (high-density layers) $[31,62,81]$. The same is principally true for sublimation and condensation at the snow surface $[82,83]$. However, LCL is often enclosed in clouds and hence, isotopic exchange between the snowpack and the surrounding moist air masses is probable. Condensation of water vapor at the snow surface and in the uppermost firn layers or sublimation of snow / firn into the atmosphere allow for secondary fractionation, i.e., it potentially leads to an enrichment in heavier isotopes and a decrease in the d excess of the snowpack $[82,84-86]$. Consequently, this may reduce the annual amplitude of the stable water isotope records of $\mathrm{OH}-12$ compared to $\mathrm{OH}$ precipitation. Isotopic modifications due to wind-forced firn ventilation ("wind-pumping") and/or deep-air convection can most likely be excluded due to the high snow accumulation rates. They cause the rapid advection of the snow away from the surface and through the ventilated zone $[85,86]$, and preclude intense firn metamorphism and the formation of large vertical cracks in the firn that both foster deep-air convection [87]. LCL is certainly affected by surface melt reflected by the presence of melt layers in OH-12 in austral summers 2012-2015. However, we did not find a correlation between MLT and stable water isotope records of OH-12 (Table 5) and the melt layers are mostly confined to the summer seasons. Hence, we assume that the stable water isotope composition of OH-12 is not substantially altered by infiltration, percolation and refreezing of surface meltwater throughout the core, but that possible smoothing effects are limited to the melt-affected seasons only.

Due to the exposed position of the study site, we suggest wind drift, i.e., removal and redistribution of snow, to have the largest impact on the stable water isotope composition of snow and firn, at least on sub-seasonal timescales [88,89]. Wind drift certainly leads to spatial mixing of snow with potentially different stable water isotope compositions. First, this may smooth the isotopic signal of the snowpack compared to the isotopic signal of precipitation and lead to the generally low temporal variability of the $\mathrm{OH}-12$ stable water isotope composition $[90,91]$. Secondly, the temporal correspondence between stable water isotopes in the snowpack on LCL and $\mathrm{OH}$ precipitation may be disrupted. Fernandoy et al. [31] describe the formation of an inversion layer in the lower troposphere (up to $350 \mathrm{~m}$ a.s.l.) on the western side of the northern AP during months with sea ice coverage. This may lead to a temporary de-coupling between LCL and OH station, as the stable atmospheric conditions associated with the inversion inhibit the uplift of moist air masses from sea level to LCL at $1100 \mathrm{~m}$ a.s.l. Finally, the dating uncertainty of \pm 2 months in the upper and \pm 10 months in the lower part of the firn core may also reduce the temporal correspondence between the stable water isotope records of $\mathrm{OH}-12$ and $\mathrm{OH}$ precipitation.

\subsection{Relation between Firn Core and Meteorological Records}

Post-depositional processes are likely one of the major causes for the absence of a correlation between $\delta^{18} \mathrm{O}$ and $\delta \mathrm{D}$ of $\mathrm{OH}-12$ and ERA5 near-surface air temperatures at the site. Wind drift and the presence of a cloud cover during most of the year may certainly reduce seasonal differences in the stable water isotope composition of the snowpack as previously described (see Section 4.3). Moreover, the strongly maritime character of the northern AP climate and the existence of an inversion layer during months with sea ice coverage leading to seasonally varying lapse rates may reduce the annual amplitude in near-surface air temperatures at the site [31,92]. The annual amplitude of ERA5 near-surface air temperature at $\mathrm{BH}$ and $\mathrm{OH}$ stations is about $8.2^{\circ} \mathrm{C}$ and $11.4^{\circ} \mathrm{C}(1979-2020)$, respectively. For the OH-12 drill site, the altitude-corrected ERA5 record of near-surface air temperature reveals an annual amplitude of about $10.3{ }^{\circ} \mathrm{C}$ (1979-2020). Such low annual oscillations, typical for coastal sites, are hardly captured in the stable water isotope composition of the snowpack on LCL. A weak or absent correlation between stable water isotopes in firn and near-surface air temperatures has been also observed for other coastal Antarctic regions [93,94]. Instead, the finding of a statistically significant negative correlation between firn core $\mathrm{d}$ excess and ERA5 near-surface air temperatures at LCL has been similarly 
obtained by Fernandoy et al. [31,32] for the study site. Depending on air humidity and wind speed, enhanced sublimation rates at higher air temperatures potentially leading to a decrease in the d excess as previously described (see Section 4.3) may account for the observed negative correlation. In addition, changes in moisture origin and moisture transport paths, kinetic fractionation during ice-crystal formation at supersaturation as well as changes in equilibrium fractionation rates at low temperatures are suggested as possible explanations $[90,95]$.

Differently to the period 2008-2009 [32], we did not find any seasonal cyclicity in the $\mathrm{d}$ excess record of OH-12 (Figures $6 \mathrm{~b}$ and $8 \mathrm{~b}$ ). As for $\delta^{18} \mathrm{O}$ and $\delta \mathrm{D}$, this may reflect the strong impact of post-depositional processes. Furthermore, the $\mathrm{d}$ excess of evaporated moisture and hence of precipitating air masses transported to a certain site is related to sea surface temperature and relative humidity in the source region [46]. Hence, the absence of a seasonal cycle in the $\mathrm{d}$ excess record of $\mathrm{OH}-12$ may suggest a low inter- and intra-annual variability of the contribution of different local and distal moisture sources to precipitation reaching LCL. In general, the westerly air flow exhibits the strongest influence on the study site as corroborated by wind roses derived for the individual years 2012-2015 as well as for the entire period covered by OH-12 (Supplementary Figure S4). The stable flow of the westerlies (43 out of 48 months in 2012-2015) is rarely interrupted by northerly ( 2 months) and southerly winds (3 months). Hence, we hypothesise that only if northerly and southerly wind directions predominate, sufficient moisture from distal source regions can reach the study site. In order to further constrain the origin of precipitating air masses reaching LCL, the calculation of backward trajectories would be necessary; that, however, is beyond the scope of this study. Nevertheless, Fernandoy et al. [31,32] identified the Bellingshausen Sea as the most important moisture source for precipitation at LCL based on backward trajectory analysis. This is in line with the dominance of the westerlies at the study site, which preferably foster moisture transport from the adjacent Bellingshausen Sea towards LCL. The dominant influence of local moisture sources on LCL may additionally explain the absence of a seasonal cyclicity in both the $\delta^{18} \mathrm{O}$ and $\delta \mathrm{D}$ as well as d excess records of $\mathrm{OH}-12$, since the stable water isotope composition of precipitation reaching a certain location is a function of the temperature difference between the moisture source and the precipitation site $[48,96]$. Hence, for LCL, the meteorological conditions at both the moisture source and sink may change in parallel due to their proximity, having no effect on the stable water isotope composition of precipitation arriving at the study site.

However, moisture from other sources, e.g., the South Pacific Ocean, the South American and Antarctic continents, can certainly influence the site, reflected by exceptional stable water isotope values [32]. For example, in austral autumn 2015, the high-resolution time series of $\delta^{18} \mathrm{O}$ and $\mathrm{d}$ excess exhibit their absolute extrema with respect to the period 2012-2015 (absolute maximum in $\delta^{18} \mathrm{O}:-7.0 \%$; absolute minimum in d excess: $1.4 \%$; Figures $6 \mathrm{~b}$ and $\left.8 \mathrm{a}, \mathrm{b}\right)$. From 18 to 27 March 2015, an exceptionally strong heat event followed by an extreme precipitation event occurred in northern and central Chile, extending south to continental Antarctica. Maximum air temperatures were measured at Esperanza station (EP) at the northern tip of the AP $\left(17.5^{\circ} \mathrm{C}\right.$ on 24 March 2015; Figures 1 and $\left.8 \mathrm{~d}\right)$ as a result of a widespread foehn event occurring on the leeward side of the AP [92,97]. The foehn event was triggered by an intense northwest-southeast oriented atmospheric river originating over the subtropical Pacific Ocean and reaching the northern AP on 23 March 2015. The synoptic conditions favouring the development of the atmospheric river (a deep low-pressure centre over the Amundsen-Bellingshausen Sea and a northwest-southeast oriented blocking ridge over the southeast Pacific Ocean) prevailed between 21 and 25 March 2015 [92,97]. During this period, exceptionally warm and moist air from the subtropical Pacific was largely advected towards the northern AP. Maximum near-surface air temperatures were also recorded at windward stations (e.g., Arturo Prat, San Martin and Carlini stations) [92], although not prominently visible at $\mathrm{BH}$ and $\mathrm{OH}$ stations. Considering the dating uncertainty of \pm 2 months in the upper part of the core, we conclude that the absolute extrema in the stable water isotope records of $\mathrm{OH}-12$ (Figures $6 \mathrm{~b}$ and $8 \mathrm{a}, \mathrm{b}$ ) are likely associated with 
the large-scale advection of warm air towards the northern AP during this event. This is supported by findings of Fernandoy et al. [32] who demonstrated that moisture originating from lower latitudes of the South Pacific Ocean exhibits higher $\delta^{18} \mathrm{O}$, but lower d excess values compared to proximal moisture sources in the Bellingshausen-Amundsen Sea (south of $\left.60^{\circ} \mathrm{S}\right)$.

(a)

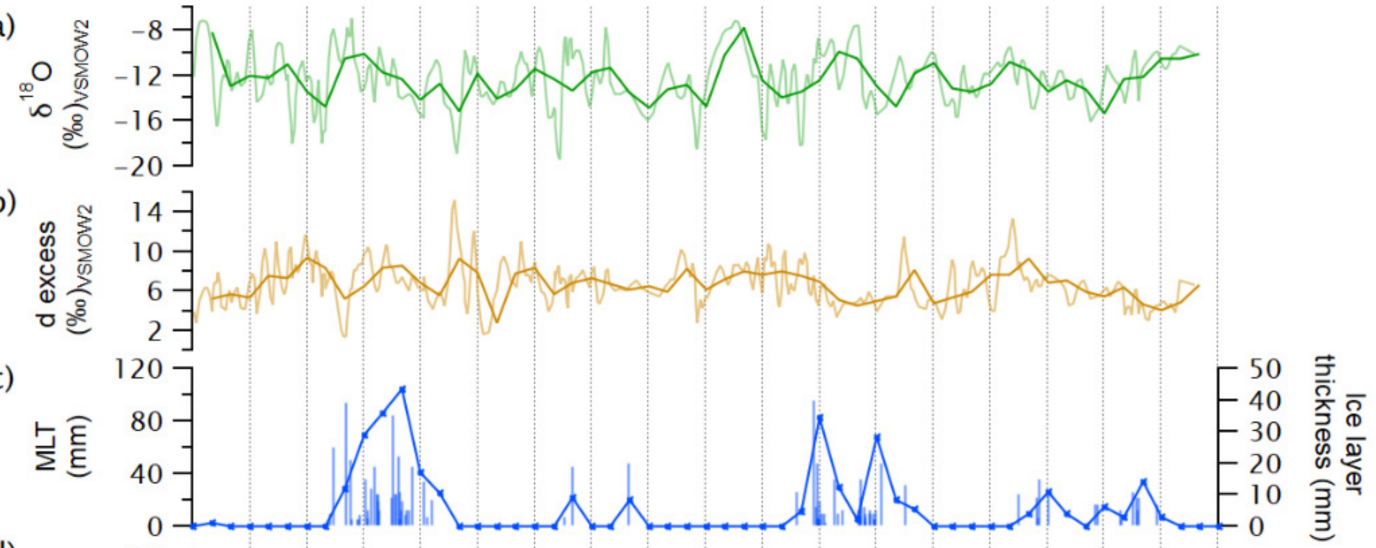

(d)

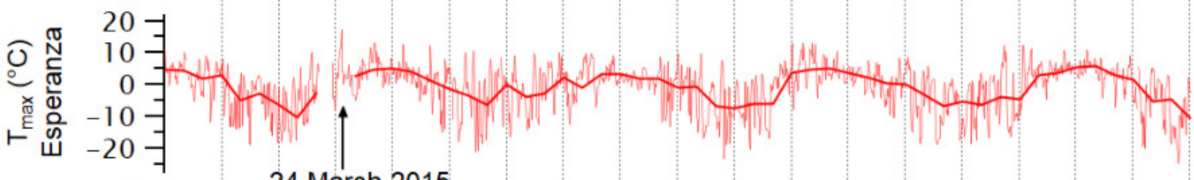

(e)

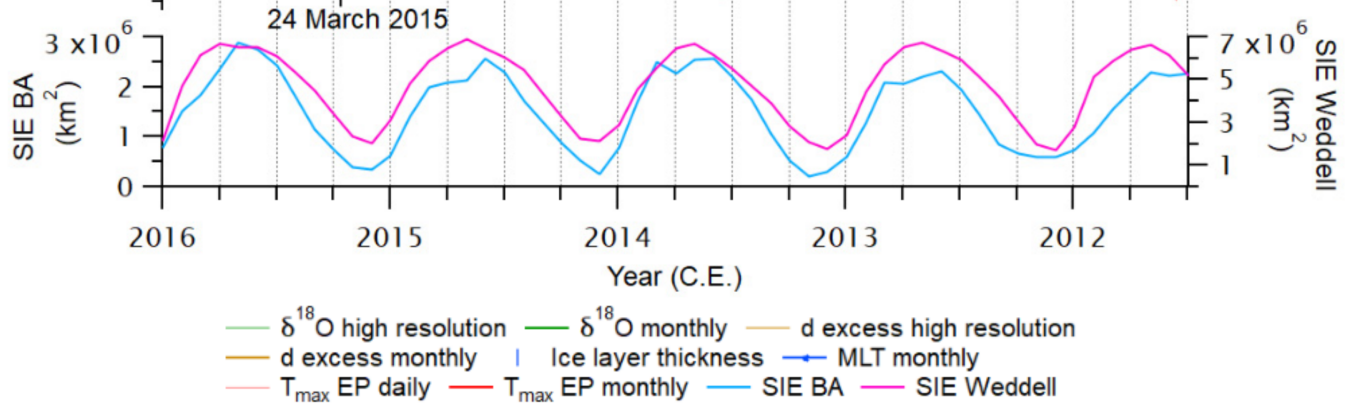

Figure 8. High-resolution (light-coloured lines) and monthly (bold lines) records of $\mathrm{OH}-12$ (a) stable oxygen isotopes (green), (b) d excess (brown) and (c) total melt layer thickness (MLT) calculated from ice layers indicating surface melt (blue) compared to the (d) AWS record of daily (light red) and monthly (red) maximum near-surface air temperature from Esperanza station (EP) and (e) monthly sea ice extent (SIE) in the Bellingshausen-Amundsen (BA; turquoise) and Weddell Seas (Weddell; pink). Esperanza maximum near-surface air temperatures were obtained from the Global Surface Summary of the Day (GSOD) of the National Centers for Environmental Information (NCEI; available at: https:/ / www.ncei.noaa.gov; last access: 15 June 2021). The day of the record high observed in Esperanza near-surface air temperatures during the atmospheric-river induced warm-air event prevailing in the northern AP region in March 2015 is indicated (d).

The atmospheric river also caused strong surface melt throughout the northern AP [98]. There are two thick melt layers $(21 \mathrm{~mm}$ and $39 \mathrm{~mm}$; Figures $4 \mathrm{~b}$ and $8 \mathrm{c}$ ) present in the $\mathrm{OH}$ 12 firn core in austral autumn 2015 which coincide with the $\delta^{18} \mathrm{O}$ and $\mathrm{d}$ excess extrema (Figures $6 \mathrm{~b}$ and $8 \mathrm{a}, \mathrm{b}$ ). Hence, we hypothesise that these ice layers correspond to surface melt occurring on LCL during the described atmospheric river event.

In general, the stratigraphic record of $\mathrm{OH}-12$ indicates that LCL is regularly affected by surface melt events (Figures 4 and $8 \mathrm{c}$ ). The advection of warm air masses from lower latitudes leading to an increased sensible heat flux probably plays the most important role in surface melt on LCL $[32,99]$. This is supported by the statistically significant positive correlation of MLT of OH-12 with ERA5 near-surface air temperatures at the site $(r=0.5, p<0.0001 ;$ Table 5). In addition, increased insolation on cloud-free days and hence the absorption of solar radiation by the snowpack can further trigger surface melt [100]. However, due to the exposed position of the study site, high wind speeds may occur year-round (Supplementary Figure S4). Hence, depending on air humidity, the absorbed 
solar radiation may not necessarily lead to strong surface melt but rather to an increased latent heat flux, i.e., enhanced evaporation/sublimation.

\subsection{Relation between Firn Core Records and Sea Ice Extent}

SIE variability in the adjacent oceans especially influences the availability of proximal and distal moisture for precipitation reaching LCL [2]. Reduced SIE will favour the transport of proximal (higher-latitude) oceanic moisture towards the northern AP with generally higher $\delta^{18} \mathrm{O}$, but lower $\mathrm{d}$ excess values due to the short distance between moisture source and sink. Increased SIE fosters both the influence of more (local) continental moisture with lower $\delta^{18} \mathrm{O}$ but higher $\mathrm{d}$ excess values, and also the contribution of distal (lower-latitude) oceanic moisture with variable characteristics depending on the conditions in the respective moisture source regions $[32,96,101]$. However, a correlation between SIE in the adjacent oceans and stable water isotopes of $\mathrm{OH}-12$ is missing or diminished due to the previously described processes (see Sections 4.3 and 4.4). Instead, it appears that inter-annual changes in SIE in the Bellingshausen-Amundsen and Weddell Seas (Figure 8e) play a role in the occurrence of strong surface melt events on LCL during the summer season. Figure 8c,e visualise the anti-correlation between MLT and SIE in both the Bellingshausen-Amundsen Sea and the Weddell Sea $(r>-0.6, p=0$; Table 5$)$. The observed anti-correlation may partly result from the fact that changes in MLT and SIE are both governed by variations in the magnitude of atmospheric and oceanic warming during the summer season. However, surface melt and SIE may be also directly related. In general, a decrease in SIE leads to more open water and lower albedo favouring stronger warming of the atmosphere and, thus, enhancing the sensible heat flux. This in turn favours surface melt. Accordingly, high MLT values in austral summers 2013 and 2015 coincide with lower SIE, especially in the Bellingshausen-Amundsen Sea, compared to the other two years (Figure 8c,e). In 2013, SIE in the Bellingshausen-Amundsen Sea is up to $21 \%$ and $34 \%$ lower during DJF and MAM, respectively, compared to 2012 and 2014. In 2015, it is reduced by up to 14\% during DJF and up to $16 \%$ during MAM (Figure 8e). The respective differences in SIE in the Weddell Sea are less pronounced. In 2013, SIE is reduced by up to $11 \%$ during both DJF and MAM, whereas in 2015, it is even slightly increased compared to 2012 and 2014 (up to $4 \%$ during DJF and 10\% during MAM; Figure 8e). Hence, we conclude that reduced SIE in the close-by Bellingshausen-Amundsen Sea likely favours the occurrence of strong surface melt events on LCL. However, warm-air advection from lower latitudes remains the main driver, as evidenced by the exceptional heat event in March 2015 likely causing strong surface melt on LCL.

\section{Conclusions}

In this study, we examined a $20 \mathrm{~m}$ long firn core retrieved from Plateau Laclavere located at the northern tip of the Antarctic Peninsula in austral summer 2016. Annual layer counting applied to the well-preserved high-resolution $\mathrm{H}_{2} \mathrm{O}_{2}$ record of $\mathrm{OH}-12$ revealed that the firn core covers a period of four full years (2012-2015).

We show that distinct maxima in the $\mathrm{BC}$, nssS and nssS/ssNa records of $\mathrm{OH}-12$ are probably linked to natural atmospheric emissions originating on the South American continent. Sources for BC are likely vast forest fire events in Chile and Argentina in 2011/2012 and 2015, and for nssS and nssS/ssNa, the eruptions of the southern Chilean volcanoes Puyehue-Cordón Caulle and Calbuco in 2011-2012 and 2015, respectively.

Snow accumulation in 2012-2015 was calculated to about $2500 \mathrm{~kg} \mathrm{~m}^{-2} \mathrm{a}^{-1}$ on average with low inter-annual variability (on average $\pm 8 \%$ ), confirming LCL as a highaccumulation site.

Comparison between stable water isotopes of $\mathrm{OH}-12$ and precipitation samples from Bernardo O'Higgins station reveals limited similarities. This implies that the isotopic signal of precipitation reaching the study site is modified during and/or after transfer into the snowpack, mainly due to orographic effects and post-depositional processes. Stable water isotope records of firn core $\mathrm{OH}-12$ show no seasonal cyclicity either in the $\delta$ values or in 
the $\mathrm{d}$ excess, most likely because of the maritime character of the northern AP climate and the impact of local post-depositional processes.

The study site is strongly influenced by the westerlies. Hence, we conclude that moisture reaching LCL primarily originates from proximal oceanic sources. The influence of moisture from more distal sources (e.g., South Pacific Ocean) is reflected in an exceptional stable water isotope composition of the snowpack. We demonstrate that stable water isotopes of $\mathrm{OH}-12$ likely record an extreme warm-air event occurring in the northern AP region in austral autumn 2015. An intense atmospheric river prevailing over the Pacific Ocean between 21 and 25 March 2015 caused the large-scale advection of exceptionally warm and moist air from the subtropical Pacific towards the northern AP and caused record high air temperatures throughout the region. Concurrently with this event, $\delta^{18} \mathrm{O}$ and $\mathrm{d}$ excess values of $\mathrm{OH}-12$ reach their respective absolute maximum and minimum in the covered period.

Furthermore, the stratigraphy of OH-12 indicates strong surface melt events on LCL, especially in austral summers 2013 and 2015. Warm-air advection from lower latitudes towards the northern AP is probably the most important trigger for surface melt on LCL. Thick melt layers found in OH-12 in austral autumn 2015 provide evidence that surface melt on LCL was likely related to the atmospheric-river induced warm-air event prevailing in the region in March 2015. In addition, we show that seasonal and inter-annual variations in SIE in the nearby Bellingshausen-Amundsen Sea likely play a role in the occurrence of surface melt on LCL.

In summary, we demonstrate that the ice cap on LCL as a high-accumulation site records meteorological and environmental signals in its glacio- and isotope-geochemical composition on sub-annual timescales and documents a clear connection to the South American continent. However, longer records from a deeper ice core will be necessary to reliably assess whether stable water isotopes from the ice cap on LCL can provide insights into past and present climate changes in the northern AP region on multi-decadal to multi-centennial timescales.

Supplementary Materials: The following are available online at https:/ /www.mdpi.com/article/10 $.3390 /$ geosciences11100428/s1, Equation (S1): Calculation of ssNa values, Equation (S2): Calculation of nssS values, Equation (S3): Calculation of wind directions at 850 mbar geopotential height, Supplementary Table S1: Coordinates and altitude of the geographic location and the nearest ERA5 grid point for the Antarctic stations Bernardo $\mathrm{O}^{\prime}$ Higgins (OH), Bellingshausen (BH), Esperanza (EP) and Comandante Ferraz (CF), as well as for the OH-12 drill site on Plateau Laclavere (LCL), Supplementary Figure S1: Thickness distribution of OH-12 ice layers that are indicating surface melt, Supplementary Figure S2: Monthly distribution of precipitation samples collected at Bernardo O'Higgins station from (a) January 2008 to March 2009, from (b) March to November 2014, and from (c) December 2015 to December 2017, Supplementary Figure S3: Comparison of the (a) stable oxygen and hydrogen isotope and (b) d excess records of firn core $\mathrm{OH}-12$ and precipitation samples collected at Bernardo O'Higgins station (OH) in the year 2014, Supplementary Figure S4: Wind roses for the study site on Plateau Laclavere derived for the single years 2012-2015 as well as for the entire period based on ERA5 monthly records of the zonal and meridional components of the $850 \mathrm{mbar}$ geopotential height wind extracted for the grid point closest to the OH-12 drill site.

Author Contributions: F.F. designed the study and carried out the fieldwork, supported by K.H.-A. and H.M. K.H.-A. and H.M. performed the stable water analyses of firn core OH-12. K.H.-A. and J.R.M. performed the glacio-chemical analyses of $\mathrm{OH}-12$. High-resolution density profiles of $\mathrm{OH}-12$ were measured by K.H.-A. and J.F. K.H-A. was responsible for data analysis, interpretation and writing of the manuscript, supported by H.M., C.S., F.F. and T.O. All authors contributed to the data interpretation and the preparation of the final manuscript. All authors have read and agreed to the published version of the manuscript.

Funding: The presented work was partially funded by the FONDECYT project 11121551. K.H.-A. was funded by an Elsa-Neumann Ph.D. scholarship awarded by the state of Berlin, Germany.

Data Availability Statement: The data will be made publicly available via https:/ /www.pangaea.de. 
Acknowledgments: We thank the Chilean government, i.e., the Instituto Antártico Chileno (INACH) and the Fuerza Área de Chile (FACH) for their support in the organisation of field campaigns and for providing logistical facilities. We highly acknowledge the support of Delia Rodríguez Oroz in carrying out fieldwork and the support of the involved laboratory personnel at AWI and DRI. We also thank two anonymous referees for their constructive comments that helped to substantially improve the manuscript.

Conflicts of Interest: The authors declare no conflict of interest. The funders had no role in the design of the study; in the collection, analyses or interpretation of data; in the writing of the manuscript, or in the decision to publish the results.

\section{References}

1. Turner, J.; Marshall, G.J.; Clem, K.; Colwell, S.; Phillips, T.; Lu, H. Antarctic temperature variability and change from station data. Int. J. Clim. 2020, 40, 2986-3007. [CrossRef]

2. Thomas, E.R.; Tetzner, D.R. The Climate of the Antarctic Peninsula during the Twentieth Century: Evidence from Ice Cores. In Antarctica-A Key to Global Change; Kanao, M., Ed.; IntechOpen: London, UK, 2019.

3. Jones, M.E.; Bromwich, D.H.; Nicolas, J.P.; Carrasco, J.; Plavcová, E.; Zou, X.; Wang, S.-H. Sixty Years of Widespread Warming in the Southern Middle and High Latitudes (1957-2016). J. Clim. 2019, 32, 6875-6898. [CrossRef]

4. Turner, J.; Lachlan-Cope, T.; Colwell, S.; Marshall, G.J. A positive trend in western Antarctic Peninsula precipitation over the last 50 years reflecting regional and Antarctic-wide atmospheric circulation changes. Ann. Glaciol. 2005, 41, 85-91. [CrossRef]

5. Thomas, E.R.; van Wessem, J.M.; Roberts, J.; Isaksson, E.; Schlosser, E.; Fudge, T.J.; Vallelonga, P.; Medley, B.; Lenaerts, J.; Bertler, N.; et al. Regional Antarctic snow accumulation over the past 1000 years. Clim. Past 2017, 13, 1491-1513. [CrossRef]

6. Medley, B.; Thomas, E.R. Increased snowfall over the Antarctic Ice Sheet mitigated twentieth-century sea-level rise. Nat. Clim. Chang. 2019, 9, 34-39. [CrossRef]

7. Pritchard, H.D.; Vaughan, D.G. Widespread acceleration of tidewater glaciers on the Antarctic Peninsula. J. Geophys. Res. 2007, 112. [CrossRef]

8. Cook, A.J.; Vaughan, D.G. Overview of areal changes of the ice shelves on the Antarctic Peninsula over the past 50 years. Cryosphere 2010, 4, 77-98. [CrossRef]

9. Pritchard, H.D.; Ligtenberg, S.R.M.; Fricker, H.A.; Vaughan, D.G.; van den Broeke, M.R.; Padman, L. Antarctic ice-sheet loss driven by basal melting of ice shelves. Nature 2012, 484, 502-505. [CrossRef] [PubMed]

10. Cook, A.J.; Holland, P.R.; Meredith, M.P.; Murray, T.; Luckman, A.; Vaughan, D.G. Ocean forcing of glacier retreat in the western Antarctic Peninsula. Science 2016, 353, 283-286. [CrossRef] [PubMed]

11. The IMBIE Team. Mass balance of the Antarctic Ice Sheet from 1992 to 2017. Nature 2018, 558, 219-222. [CrossRef]

12. Stenni, B.; Curran, M.A.J.; Abram, N.J.; Orsi, A.; Goursaud, S.; Masson-Delmotte, V.; Neukom, R.; Goosse, H.; Divine, D.; van Ommen, T.; et al. Antarctic climate variability on regional and continental scales over the last 2000 years. Clim. Past 2017, 13, 1609-1634. [CrossRef]

13. Mulvaney, R.; Abram, N.J.; Hindmarsh, R.C.A.; Arrowsmith, C.; Fleet, L.; Triest, J.; Sime, L.C.; Alemany, O.; Foord, S. Recent Antarctic Peninsula warming relative to Holocene climate and ice-shelf history. Nature 2012, 489, 141-144. [CrossRef] [PubMed]

14. Thompson, D.W.J.; Solomon, S. Interpretation of Recent Southern Hemisphere Climate Change. Science 2002, 296, 895-899. [CrossRef]

15. Marshall, G.J. Trends in the Southern Annular Mode from Observations and Reanalyses. J. Clim. 2003, 16, 4134-4143. [CrossRef]

16. Dickens, W.A.; Kuhn, G.; Leng, M.J.; Graham, A.G.C.; Dowdeswell, J.A.; Meredith, M.P.; Hillenbrand, C.-D.; Hodgson, D.A.; Roberts, S.; Sloane, H.; et al. Enhanced glacial discharge from the eastern Antarctic Peninsula since the 1700s associated with a positive Southern Annular Mode. Sci. Rep. 2019, 9, 14606. [CrossRef] [PubMed]

17. Clem, K.R.; Renwick, J.A.; McGregor, J.; Fogt, R.L. The relative influence of ENSO and SAM on Antarctic Peninsula climate. J. Geophys. Res. Atmos. 2016, 121, 9324-9341. [CrossRef]

18. Marshall, G.J.; Orr, A.; Van Lipzig, N.P.M.; King, J.C. The Impact of a Changing Southern Hemisphere Annular Mode on Antarctic Peninsula Summer Temperatures. J. Clim. 2006, 19, 5388-5404. [CrossRef]

19. Turner, J.; Barrand, N.E.; Bracegirdle, T.J.; Convey, P.; Hodgson, D.A.; Jarvis, M.; Jenkins, A.; Marshall, G.; Meredith, M.P.; Roscoe, H.; et al. Antarctic climate change and the environment: An update. Polar Rec. 2014, 50, 237-259. [CrossRef]

20. Orr, A.; Cresswell, D.; Marshall, G.J.; Hunt, J.C.R.; Sommeria, J.; Wang, C.G.; Light, M. A 'low-level' explanation for the recent large warming trend over the western Antarctic Peninsula involving blocked winds and changes in zonal circulation. Geophys. Res. Lett. 2004, 31. [CrossRef]

21. Parkinson, C.L.; Cavalieri, D.J. Antarctic sea ice variability and trends, 1979-2010. Cryosphere 2012, 6, 871-880. [CrossRef]

22. Porter, S.E.; Parkinson, C.L.; Mosley-Thompson, E. Bellingshausen Sea ice extent recorded in an Antarctic Peninsula ice core. J. Geophys. Res. Atmos. 2016, 121, 13886-13900. [CrossRef]

23. Kumar, A.; Yadav, J.; Mohan, R. Seasonal sea-ice variability and its trend in the Weddell Sea sector of West Antarctica. Environ. Res. Lett. 2021, 16, 024046. [CrossRef]

24. Turner, J.; Phillips, T.; Hosking, J.S.; Marshall, G.J.; Orr, A. The Amundsen Sea low. Int. J. Climatol. 2013, 33, 1818-1829. [CrossRef] 
25. Murphy, E.J.; Clarke, A.; Abram, N.; Turner, J. Variability of sea-ice in the northern W eddell S ea during the 20th century. J. Geophys. Res. Oceans 2014, 119, 4549-4572. [CrossRef]

26. Turner, J.; Lu, H.; White, I.; King, J.C.; Phillips, T.; Hosking, J.S.; Bracegirdle, T.J.; Marshall, G.J.; Mulvaney, R.; Deb, P. Absence of 21st century warming on Antarctic Peninsula consistent with natural variability. Nature 2016, 535, 411-415. [CrossRef] [PubMed]

27. Oliva, M.; Navarro, F.J.; Hrbáček, F.; Hernández, A.; Nývlt, D.; Pereira, P.; Ruiz-Fernández, J.; Trigo, R. Recent regional climate cooling on the Antarctic Peninsula and associated impacts on the cryosphere. Sci. Total Environ. 2017, 580, 210-223. [CrossRef] [PubMed]

28. Bozkurt, D.; Bromwich, D.H.; Carrasco, J.; Hines, K.M.; Maureira, J.C.; Rondanelli, R. Recent Near-surface Temperature Trends in the Antarctic Peninsula from Observed, Reanalysis and Regional Climate Model Data. Adv. Atmos. Sci. 2020, 37, 477-493. [CrossRef]

29. Bromwich, D.H.; Nicolas, J.P.; Monaghan, A.J.; Lazzara, M.A.; Keller, L.M.; Weidner, G.A.; Wilson, A.B. Central West Antarctica among the most rapidly warming regions on Earth. Nat. Geosci. 2012, 6, 139-145. [CrossRef]

30. Goodwin, B.P.; Mosley-Thompson, E.; Wilson, A.B.; Porter, S.E.; Sierra-Hernandez, M.R. Accumulation Variability in the Antarctic Peninsula: The Role of Large-Scale Atmospheric Oscillations and Their Interactions. J. Clim. 2016, 29, 2579-2596. [CrossRef]

31. Fernandoy, F.; Tetzner, D.; Meyer, H.; Gacitúa, G.; Hoffmann, K.; Falk, U.; Lambert, F.; MacDonell, S. New insights into the use of stable water isotopes at the northern Antarctic Peninsula as a tool for regional climate studies. Cryosphere 2018, 12, 1069-1090. [CrossRef]

32. Fernandoy, F.; Meyer, H.; Tonelli, M. Stable water isotopes of precipitation and firn cores from the northern Antarctic Peninsula region as a proxy for climate reconstruction. Cryosphere 2012, 6, 313-330. [CrossRef]

33. Cárdenas, C.; Johnson, E.; Fernandoy, F.; Meyer, H.; Cereceda, F.; Vidal, V. Preliminary results of the superficial and subglacier topography survey using Radio Echo Sounding at the La Claveré Plateau, Antarctic Peninsula. In Proceedings of the SCAR Open Science Conference, Auckland, New Zealand, 1-3 September 2014.

34. Freitag, J.; Kipfstuhl, S.; Laepple, T. Core-scale radioscopic imaging: A new method reveals density-calcium link in Antarctic firn. J. Glaciol. 2013, 59, 1009-1014. [CrossRef]

35. van Geldern, R.; Barth, J.A. Optimization of instrument setup and post-run corrections for oxygen and hydrogen stable isotope measurements of water by isotope ratio infrared spectroscopy (IRIS). Limnol. Oceanogr. Methods 2012, 10, 1024-1036. [CrossRef]

36. Röthlisberger, R.; Bigler, M.; Hutterli, M.; Sommer, S.; Stauffer, B.; Junghans, H.G.; Wagenbach, D. Technique for Continuous High-Resolution Analysis of Trace Substances in Firn and Ice Cores. Environ. Sci. Technol. 2000, 34, 338-342. [CrossRef]

37. McConnell, J.R.; Lamorey, G.W.; Lambert, S.W.; Taylor, K.C. Continuous Ice-Core Chemical Analyses Using Inductively Coupled Plasma Mass Spectrometry. Environ. Sci. Technol. 2002, 36, 7-11. [CrossRef]

38. Röthlisberger, R.; Mulvaney, R.; Wolff, E.W.; Hutterli, M.A.; Bigler, M.; Sommer, S.; Jouzel, J. Dust and sea salt variability in central East Antarctica (Dome C) over the last 45 kyrs and its implications for southern high-latitude climate. Geophys. Res. Lett. 2002, 29, 24-1-24-4. [CrossRef]

39. Sigl, M.; McConnell, J.R.; Layman, L.; Maselli, O.; McGwire, K.C.; Pasteris, D.R.; Dahl-Jensen, D.; Steffensen, J.P.; Vinther, B.; Edwards, R.; et al. A new bipolar ice core record of volcanism from WAIS Divide and NEEM and implications for climate forcing of the last 2000 years. J. Geophys. Res. Atmos. 2013, 118, 1151-1169. [CrossRef]

40. Bowen, H. Environmental Chemistry of the Elements; Academic Press: London, UK; New York, NY, USA, 1979.

41. McConnell, J.R.; Edwards, R.; Kok, G.L.; Flanner, M.G.; Zender, C.S.; Saltzman, E.S.; Banta, J.R.; Pasteris, D.R.; Carter, M.M.; Kahl, J.D.W. 20th-Century Industrial Black Carbon Emissions Altered Arctic Climate Forcing. Science 2007, 317, 1381-1384. [CrossRef] [PubMed]

42. Bond, T.; Doherty, S.; Fahey, D.; Forster, P.; Berntsen, T.; DeAngelo, B.J.; Flanner, M.; Ghan, S.; Kaercher, B.; Koch, D.; et al. Bounding the role of black carbon in the climate system: A scientific assessment. J. Geophys. Res. Atmos. 2013, 118, 5380-5552. [CrossRef]

43. Delmas, R.J.; Legrand, M.; Aristarain, A.J.; Zanolini, F. Volcanic deposits in Antarctic snow and ice. J. Geophys. Res. 1985, 90, 901-912. [CrossRef]

44. Cole-Dai, J.; Mosley-Thompson, E.; Thompson, L.G. Annually resolved southern hemisphere volcanic history from two Antarctic ice cores. J. Geophys. Res. 1997, 102, 16761-16771. [CrossRef]

45. Dansgaard, W. Stable isotopes in precipitation. Tellus 1964, 16, 436-468. [CrossRef]

46. Merlivat, L.; Jouzel, J. Global climatic interpretation of the deuterium-oxygen 18 relationship for precipitation. J. Geophys. Res. 1979, 84, 5029-5033. [CrossRef]

47. Uemura, R.; Matsui, Y.; Yoshimura, K.; Motoyama, H.; Yoshida, N. Evidence of deuterium excess in water vapor as an indicator of ocean surface conditions. J. Geophys. Res. 2008, 113, D19114. [CrossRef]

48. Stenni, B.; Masson-Delmotte, V.; Selmo, E.; Oerter, H.; Meyer, H.; Röthlisberger, R.; Jouzel, J.; Cattani, O.; Falourd, S.; Fischer, H.; et al. The deuterium excess records of EPICA Dome C and Dronning Maud Land ice cores (East Antarctica). Quat. Sci. Rev. 2010, 29, 146-159. [CrossRef]

49. Craig, H. Isotopic Variations in Meteoric Waters. Science 1961, 133, 1702-1703. [CrossRef]

50. McConnell, J.R.; Winterle, J.R.; Stewart, R.W.; Bales, R.C.; Thompson, A.M. Physically based inversion of surface snow concentrations of $\mathrm{H}_{2} \mathrm{O}_{2}$ to atmospheric concentrations at South Pole. Geophys. Res. Lett. 1997, 24, 441-444. [CrossRef] 
51. Riedel, K.; Weller, R.; Schrems, O.; König-Langlo, G. Variability of tropospheric hydroperoxides at a coastal surface site in Antarctica. Atmos. Environ. 2000, 34, 5225-5234. [CrossRef]

52. Lee, M.; Heikes, B.G.; O'Sullivan, D.W. Hydrogen peroxide and organic hydroperoxide in the troposphere: A review. Atmospheric Environ. 2000, 34, 3475-3494. [CrossRef]

53. Stewart, R.W. The annual cycle of hydrogen peroxide: An indicator of chemical instability? Atmos. Chem. Phys. Discuss. 2004, 4, 933-946. [CrossRef]

54. Frey, M.M.; Bales, R.C.; McConnell, J.R. Climate sensitivity of the century-scale hydrogen peroxide $\left(\mathrm{H}_{2} \mathrm{O}_{2}\right)$ record preserved in 23 ice cores from West Antarctica. J. Geophys. Res. 2006, 111. [CrossRef]

55. Hersbach, H.; Bell, B.; Berrisford, P.; Hirahara, S.; Horanyi, A.; Muñoz-Sabater, J.; Nicolas, J.; Peubey, C.; Radu, R.; Schepers, D.; et al. The ERA5 global reanalysis. Q. J. R. Meteorol. Soc. 2020, 146, 1999-2049. [CrossRef]

56. Trouet, V.; van Oldenborgh, G.J. KNMI Climate Explorer: A Web-Based Research Tool for High-Resolution Paleoclimatology. Tree-Ring Res. 2013, 69, 3-13. [CrossRef]

57. Cavalieri, D.J.; Parkinson, C.; Gloersen, P.; Comiso, J.C.; Zwally, H.J. Deriving long-term time series of sea ice cover from satellite passive-microwave multisensor data sets. J. Geophys. Res. Space Phys. 1999, 104, 15803-15814. [CrossRef]

58. Cavalieri, D.J.; Parkinson, C.L.; DiGirolamo, N.; Ivanoff, A. Intersensor Calibration Between F13 SSMI and F17 SSMIS for Global Sea Ice Data Records. IEEE Geosci. Remote Sens. Lett. 2011, 9, 233-236. [CrossRef]

59. McConnell, J.R.; Bales, R.C.; Stewart, R.W.; Thompson, A.M.; Albert, M.R.; Ramos, R. Physically based modeling of atmosphereto-snow-to-firn transfer of $\mathrm{H}_{2} \mathrm{O}_{2}$ at South Pole. J. Geophys. Res. 1998, 103, 10561-10570. [CrossRef]

60. Thomas, E.R.; Bracegirdle, T.J. Improving ice core interpretation using in situ and reanalysis data. J. Geophys. Res. 2009, 114. [CrossRef]

61. Sinclair, K.E.; Bertler, N.A.N.; Trompetter, W.J. Synoptic controls on precipitation pathways and snow delivery to highaccumulation ice core sites in the Ross Sea region, Antarctica. J. Geophys. Res. 2010, 115. [CrossRef]

62. Casado, M.; Münch, T.; Laepple, T. Climatic information archived in ice cores: Impact of intermittency and diffusion on the recorded isotopic signal in Antarctica. Clim. Past 2020, 16, 1581-1598. [CrossRef]

63. Das, S.B.; Alley, R.B. Characterization and formation of melt layers in polar snow: Observations and experiments from West Antarctica. J. Glaciol. 2005, 51, 307-312. [CrossRef]

64. Orsi, A.J.; Kawamura, K.; Fegyveresi, J.; Headly, M.A.; Alley, R.B.; Severinghaus, J.P. Differentiating bubble-free layers from melt layers in ice cores using noble gases. J. Glaciol. 2015, 61, 585-594. [CrossRef]

65. Global Volcanism Program. Puyehue-Cordón Caulle (357150). In Volcanoes of the World; Venzke, E., Ed.; Smithsonian Institution: Washington, DC, USA, 2013. [CrossRef]

66. Koffman, B.G.; Dowd, E.G.; Osterberg, E.C.; Ferris, D.G.; Hartman, L.H.; Wheatley, S.D.; Kurbatov, A.V.; Wong, G.J.; Markle, B.; Dunbar, N.W.; et al. Rapid transport of ash and sulfate from the 2011 Puyehue-Cordón Caulle (Chile) eruption to West Antarctica. J. Geophys. Res. Atmos. 2017, 122, 8908-8920. [CrossRef]

67. Bègue, N.; Vignelles, D.; Berthet, G.; Portafaix, T.; Payen, G.; Jégou, F.; Benchérif, H.; Jumelet, J.; Vernier, J.-P.; Lurton, T.; et al. Long-range transport of stratospheric aerosols in the Southern Hemisphere following the 2015 Calbuco eruption. Atmospheric Chem. Phys. Discuss. 2017, 17, 15019-15036. [CrossRef]

68. Bègue, N.; Shikwambana, L.; Bencherif, H.; Pallotta, J.; Sivakumar, V.; Wolfram, E.; Mbatha, N.; Orte, F.; Du Preez, D.J.; Ranaivombola, M.; et al. Statistical analysis of the long-range transport of the 2015 Calbuco volcanic plume from ground-based and space-borne observations. Ann. Geophys. 2020, 38, 395-420. [CrossRef]

69. Global Volcanism Program. Calbuco. In Volcanoes of the World; Venzke, E., Ed.; Smithsonian Institution: Washington, DC, USA, 2013. [CrossRef]

70. Ivy, D.J.; Solomon, S.; Kinnison, D.; Mills, M.J.; Schmidt, A.; Neely, R.R. The influence of the Calbuco eruption on the 2015 Antarctic ozone hole in a fully coupled chemistry-climate model. Geophys. Res. Lett. 2017, 44, 2556-2561. [CrossRef]

71. Evangelista, H.; Sodré, E.D.; Lima, A.C.M. Preliminary Investigation on the Atmospheric Dispersion of Pollutants Due to Ferraz Fire. INCT-APA 2013, 35-42. [CrossRef]

72. Wolff, E.; Cachier, H. Concentrations and seasonal cycle of black carbon in aerosol at a coastal Antarctic station. J. Geophys. Res. 1998, 103, 11033-11041. [CrossRef]

73. Pereira, E.B.; Evangelista, H.; Pereira, K.C.D.; Cavalcanti, I.F.A.; Setzer, A.W. Apportionment of black carbon in the South Shetland Islands, Antarctic Peninsula. J. Geophys. Res. 2006, 111, D03303. [CrossRef]

74. Fiebig, M.; Lunder, C.R.; Stohl, A. Tracing biomass burning aerosol from South America to Troll Research Station, Antarctica. Geophys. Res. Lett. 2009, 36. [CrossRef]

75. Jumelet, J.; Klekociuk, A.R.; Alexander, S.P.; Bekki, S.; Hauchecorne, A.; Vernier, J.P.; Fromm, M.; Keckhut, P. Detection of Aerosols in Antarctica from Long-Range Transport of the 2009 Australian Wildfires. J. Geophys. Res. Atmos. 2020, 125. [CrossRef]

76. Mattar, C.; Santamaría-Artigas, A.; Durán-Alarcón, C. Estimación del área quemada en el Parque Nacional Torres del Paine utilizando datos de teledetección. Rev. Teledetec. 2012, 38, 36-50.

77. Medina, R.C. Mega Wildfire in the World Biosphere Reserve (UNESCO), Torres del Paine National Park, Patagonia-Chile 2012: Work Experience in Extreme Behavior Conditions in the Context of Global Warming. In Proceedings of the Fourth International Symposium on Fire Economics, Planning, and Policy: Climate Change and Wildfires, General Technical Report PSW-GTR-245; González-Cabán, A., Ed.; U.S. Department of Agriculture, Forest Service, Pacific Southwest Research Station: Albany, CA, USA, 2013; pp. $191-201$. 
78. Otero, L.A.; Roberto Ristori, P.; Garcia Ferreyra, M.F.; Aguirre, D.; Raponi, M.M.; Omar Salvador, J.; DElia, R.; Martorella, E.; Pereyra, A.F.; Vilar, O.; et al. Biomass Burning Detection at Comodoro Rivadavia and Trelew on March 1st, 2015. In Proceedings of the 2018 IEEE Biennial Congress of Argentina (ARGENCON), San Miguel de Tucumán, Argentina, 6-8 June 2018; pp. 1-8.

79. Liu, P.; Kaplan, J.O.; Mickley, L.J.; Li, Y.; Chellman, N.J.; Arienzo, M.M.; Kodros, J.K.; Pierce, J.R.; Sigl, M.; Freitag, J.; et al. Improved estimates of preindustrial biomass burning reduce the magnitude of aerosol climate forcing in the Southern Hemisphere. Sci. Adv. 2021, 7, eabc1379. [CrossRef] [PubMed]

80. Rozanski, K.; Araguás-Araguás, L.; Gonfiantini, R. Isotopic Patterns in Modern Global Precipitation. In Climate Change in Continental Isotopic Records; Swart, P.K., Lohmann, K.C., Mckenzie, J., Savin, S., Eds.; Geophysical Monograph Series; American Geophysical Union: Washington, DC, USA, 1993; pp. 1-36.

81. Cuffey, K.M.; Steig, E.J. Isotopic diffusion in polar firn: Implications for interpretation of seasonal climate parameters in ice-core records, with emphasis on central Greenland. J. Glaciol. 1998, 44, 273-284. [CrossRef]

82. Neumann, T.A.; Albert, M.R.; Lomonaco, R.; Engel, C.; Courville, Z.; Perron, F. Experimental determination of snow sublimation rate and stable-isotopic exchange. Ann. Glaciol. 2008, 49, 1-6. [CrossRef]

83. Neumann, T.A.; Waddington, E.D.; Steig, E.J.; Grootes, P.M. Non-climate influences on stable isotopes at Taylor Mouth, Antarctica. J. Glaciol. 2005, 51, 248-258. [CrossRef]

84. Ritter, F.; Steen-Larsen, H.C.; Werner, M.; Masson-Delmotte, V.; Orsi, A.; Behrens, M.; Birnbaum, G.; Freitag, J.; Risi, C.; Kipfstuhl, S. Isotopic exchange on the diurnal scale between near-surface snow and lower atmospheric water vapor at Kohnen station, East Antarctica. Cryosphere 2016, 10, 1647-1663. [CrossRef]

85. Town, M.S.; Warren, S.G.; Walden, V.P.; Waddington, E.D. Effect of atmospheric water vapor on modification of stable isotopes in near-surface snow on ice sheets. J. Geophys. Res. Space Phys. 2008, 113. [CrossRef]

86. Neumann, T.A.; Waddington, E.D. Effects of firn ventilation on isotopic exchange. J. Glaciol. 2004, 50, 183-194. [CrossRef]

87. Severinghaus, J.P.; Albert, M.; Courville, Z.; Fahnestock, M.A.; Kawamura, K.; Montzka, S.; Mühle, J.; Scambos, T.A.; Shields, E.; Shuman, C.A.; et al. Deep air convection in the firn at a zero-accumulation site, central Antarctica. Earth Planet. Sci. Lett. 2010, 293, 359-367. [CrossRef]

88. van Lipzig, N.P.M.; King, J.C.; Lachlan-Cope, T.A.; van den Broeke, M.R. Precipitation, sublimation, and snow drift in the Antarctic Peninsula region from a regional atmospheric model. J. Geophys. Res. 2004, 109, D24. [CrossRef]

89. Casado, M.; Landais, A.; Picard, G.; Münch, T.; Laepple, T.; Stenni, B.; Dreossi, G.; Ekaykin, A.; Arnaud, L.; Genthon, C.; et al. Archival processes of the water stable isotope signal in East Antarctic ice cores. Cryosphere 2018, 12, 1745-1766. [CrossRef]

90. Masson-Delmotte, V.; Hou, S.; Ekaykin, A.; Jouzel, J.; Aristarain, A.; Bernardo, R.T.; Bromwich, D.; Cattani, O.; Delmotte, M.; Falourd, S.; et al. A Review of Antarctic Surface Snow Isotopic Composition: Observations, Atmospheric Circulation, and Isotopic Modeling. J. Clim. 2008, 21, 3359-3387. [CrossRef]

91. Münch, T.; Kipfstuhl, S.; Freitag, J.; Meyer, H.; Laepple, T. Regional climate signal vs. local noise: A two-dimensional view of water isotopes in Antarctic firn at Kohnen Station, Dronning Maud Land. Clim. Past 2016, 12, 1565-1581. [CrossRef]

92. Bozkurt, D.; Rondanelli, R.; Marín, J.C.; Garreaud, R. Foehn Event Triggered by an Atmospheric River Underlies Record-Setting Temperature Along Continental Antarctica. J. Geophys. Res. Atmos. 2018, 123, 3871-3892. [CrossRef]

93. Goursaud, S.; Masson-Delmotte, V.; Favier, V.; Preunkert, S.; Fily, M.; Gallée, H.; Jourdain, B.; Legrand, M.; Magand, O.; Minster, B.; et al. A 60-year ice-core record of regional climate from Adélie Land, coastal Antarctica. Cryosphere 2017, 11, 343-362. [CrossRef]

94. Goursaud, S.; Masson-Delmotte, V.; Favier, V.; Preunkert, S.; Legrand, M.; Minster, B.; Werner, M. Challenges associated with the climatic interpretation of water stable isotope records from a highly resolved firn core from Adélie Land, coastal Antarctica. Cryosphere 2019, 13, 1297-1324. [CrossRef]

95. Jouzel, J.; Merlivat, L. Deuterium and oxygen 18 in precipitation: Modeling of the isotopic effects during snow formation. J. Geophys. Res. 1984, 89, 11749-11757. [CrossRef]

96. Masson-Delmotte, V.; Delmotte, M.; Morgan, V.; Etheridge, D.; van Ommen, T.; Tartarin, S.; Hoffmann, G. Recent southern Indian Ocean climate variability inferred from a Law Dome ice core: New insights for the interpretation of coastal Antarctic isotopic records. Clim. Dyn. 2003, 21, 153-166. [CrossRef]

97. Barrett, B.S.; Campos, D.A.; Veloso, J.V.; Rondanelli, R. Extreme temperature and precipitation events in March 2015 in central and northern Chile. J. Geophys. Res. Atmos. 2016, 121, 4563-4580. [CrossRef]

98. Wille, J.D.; Favier, V.; Dufour, A.; Gorodetskaya, I.V.; Turner, J.; Agosta, C.; Codron, F. West Antarctic surface melt triggered by atmospheric rivers. Nat. Geosci. 2019, 12, 911-916. [CrossRef]

99. van den Broeke, M. Strong surface melting preceded collapse of Antarctic Peninsula ice shelf. Geophys. Res. Lett. 2005, 32, L12815. [CrossRef]

100. Jakobs, C.L.; Reijmer, C.H.; van den Broeke, M.R.; van de Berg, W.J.; van Wessem, J.M. Spatial Variability of the Snowmelt-Albedo Feedback in Antarctica. J. Geophys. Res. Earth Surf. 2021, 126. [CrossRef]

101. Noone, D. Sea ice control of water isotope transport to Antarctica and implications for ice core interpretation. J. Geophys. Res. 2004, 109, 5029-5033. [CrossRef] 